\title{
Composition of ice particle residuals in mixed-phase clouds at Jungfraujoch (Switzerland): enrichment and depletion of particle groups relative to total aerosol
}

\author{
Stine Eriksen Hammer ${ }^{1}$, Stephan Mertes $^{2}$, Johannes Schneider ${ }^{3}$, Martin Ebert ${ }^{1}$, Konrad Kandler ${ }^{1}$, and \\ Stephan Weinbruch ${ }^{1}$ \\ ${ }^{1}$ Institute of Applied Geosciences, Darmstadt University of Technology, Schnittspahnstraße 9, 64287 Darmstadt, Germany \\ ${ }^{2}$ Leibniz-Institute for Tropospheric Research, Permoserstraße 15, 04318 Leipzig, Germany \\ ${ }^{3}$ Particle Chemistry Department, Max Planck Institute for Chemistry, Hahn-Meitner-Weg 1, 55128 Mainz, Germany
}

Correspondence: Stine Eriksen Hammer (sehammer@geo.tu-darmstadt.de)

Received: 12 May 2018 - Discussion started: 1 June 2018

Revised: 4 September 2018 - Accepted: 10 September 2018 - Published: 2 October 2018

\begin{abstract}
Ice particle residuals (IRs) and the total aerosol particle population were sampled in parallel during mixedphase cloud events at the high-altitude research station Jungfraujoch in January-February 2017. Particles were sampled behind an ice-selective counterflow impactor (Ice-CVI) for IRs and a heated total inlet for the total aerosol particles. A dilution set-up was used to collect total particles with the same sampling duration as for IRs to prevent overloading of the substrates. About 4000 particles from 10 Ice-CVI samples (from 7 days of cloud events at temperatures at the site between -10 and $-18^{\circ} \mathrm{C}$ ) were analysed and classified with operator-controlled scanning electron microscopy. Contamination particles (identified by their chemical composition), most likely originating from abrasion in the Ice-CVI and collection of secondary ice, were excluded from further analysis. Approximately 3000 total aerosol particles (IRs and interstitial particles) from 5 days in clouds were also analysed. Enrichment and depletion of the different particle groups (within the IR fraction relative to the total aerosol reservoir) are presented as an odds ratio relative to alumosilicate (particles only consisting of $\mathrm{Al}, \mathrm{Si}$, and $\mathrm{O}$ ), which was chosen as reference due to the large enrichment of this group relative to total aerosol and the relatively high number concentration of this group in both total aerosol and the IR samples. Complex secondary particles and soot are the major particle groups in the total aerosol samples but are not found in the IR fraction and are hence strongly depleted. C-rich particles (most likely organic particles) showed a smaller enrichment compared to aluminosilicates by a factor of $\sim 20$. The particle
\end{abstract}

groups with enrichment similar to aluminosilicate are silica, Fe aluminosilicates, Ca-rich particles, Ca sulfates, sea-saltcontaining particles, and metal/metal oxide. Other aluminosilicates - consisting of variable amounts of $\mathrm{Na}, \mathrm{K}, \mathrm{Ca}, \mathrm{Si}$, $\mathrm{Al}, \mathrm{O}, \mathrm{Ti}$, and $\mathrm{Fe}$ - are somewhat more enriched (factor $\sim 2$ ) and $\mathrm{Pb}$-rich particles are more (factor $\sim 8$ ) enriched than aluminosilicates. None of the sampled IR groups showed a temperature or size dependence in respect to ice activity, which might be due to the limited sampling temperature interval and the similar size of the particles. Footprint plots and wind roses could explain the different total aerosol composition in one sample (carbonaceous particle emission from the urban/industrial area of Po Valley), but this did not affect the IR composition. Taking into account the relative abundance of the particle groups in total aerosol and the ice nucleation ability, we found that silica, aluminosilicates, and other aluminosilicates were the most important ice particle residuals at Jungfraujoch during the mixed-phase cloud events in winter 2017.

\section{Introduction}

Mixed-phase clouds are important because they have an impact on the hydrological cycle and cloud electrification and because they influence the atmospheric radiation balance (Storelvmo, 2017). Ice-nucleating particles (INPs) can initiate cloud glaciation, which may cause precipitation (Myhre et al., 2013). The order of magnitude of the effect from 
aerosol-cloud interaction on the "second indirect aerosol effect" and "semi-indirect effect" is still uncertain (Myhre et al., 2013; Flato et al., 2013; Korolev et al., 2017).

In nature, spontaneous freezing of supersaturated droplets occurs at temperatures below $-38^{\circ} \mathrm{C}$ and a relative humidity with respect to ice $>\sim 140 \%$ (Kanji et al., 2017), termed homogeneous ice nucleation (Vali et al., 2015). At higher temperatures, a surface - like a particle surface - can lower the free energy and thereby assist the phase transition to ice when relative humidity allows for this, termed heterogeneous ice nucleation. Heterogeneous ice nucleation can occur in different hypothesized modes: (1) deposition nucleation, (2) immersion freezing, (3) contact freezing, and (4) condensation freezing. A detailed description of the different modes is found elsewhere (Vali et al., 2015; Kanji et al., 2017). Mixed-phase cloud temperature ranges between -40 and $0{ }^{\circ} \mathrm{C}$ (Storelvmo, 2017), with immersion and contact freezing as the dominating ice formation modes (Lohmann and Diehl, 2006).

Ice nucleation ability was studied offline and online in many laboratory and field experiments as well as by modelling (Hoose et al., 2010; Hoose and Möhler, 2012; Kanji et al., 2017, and references therein). Summarized from laboratory studies (Hoose and Möhler, 2012), biological particles seem to dominate the ice activity at higher temperatures above $-10^{\circ} \mathrm{C}$, whereas mineral dust is found to be mostly ice active below $-10^{\circ} \mathrm{C}$, and organic particles and soot nucleate ice below $-30^{\circ} \mathrm{C}$ close to homogenous freezing. A model study of mixed-phase clouds on a global scale by Hoose et al. (2010) shows that the main component of INPs is mineral dust particles. The findings of field experiments at different locations globally are presented by Kanji et al. (2017) as a function of nucleation temperature. In this paper only broadly defined classes are given to characterize the ice nucleation efficiency from INP concentration in different environments. To summarize, biological particles from rural areas dominate at higher temperatures $\left(-5\right.$ to $\left.-20^{\circ} \mathrm{C}\right)$, and marine particles from coastal areas show a lower ice activity in the higher temperature range than biological particles ( -5 to $-30^{\circ} \mathrm{C}$ ). Particles from Arctic and Antarctic locations seem to have a relatively high INP abundance between -17 and $-25^{\circ} \mathrm{C}$, and particles from areas with biomass burning show high INP concentrations between -10 and $-30^{\circ} \mathrm{C}$. Mineraldust-rich regions show particles with the highest ice activity in the range of -10 to $-40^{\circ} \mathrm{C}$, and these particles seem to be the most ice-active component. Exact number concentration is found in Kanji et al. (2017) and references therein. Particle groups determined based on chemical composition in cirrus clouds are reported as sulfates, organics, sea salt, mineral dust or fly ash, metal particles, soot, and biological material in the ice particle residual (IR) fraction (Heintzenberg et al., 1996; Cziczo et al., 2004, 2013). Twohy and Poellot (2005) found the highest abundance of salts and industrial particles in cirrus, followed by crustal, organic and soot particles. In mixed-phase clouds, at the high-altitude research sta- tion Jungfraujoch in Switzerland, different IR groups were reported to act as ice nuclei. With the use of electron microscopy and looking at the enrichment relative to interstitial aerosol, Ebert et al. (2011) interpreted complex secondary aerosol, $\mathrm{Pb}$-bearing particles, and complex mixtures as ice nuclei. In contrast, Worringen et al. (2015) considered only particle groups as ice nuclei, which were found with three different techniques (FINCH + PCVI, Ice-CVI, and ISI). These groups included silicates, Ca-rich particles, carbonaceous particles, metal/metal oxide, and soot. Using single-particle mass spectrometry, Schmidt et al. (2017) considered all particles observed in the IR fraction as INPs (biological, soil dust, minerals, sea salt/cooking, aged material, engine exhaust, soot, lead-containing particles, industrial metals, Na- and K-dominated particles, and others). Kamphus et al. (2010) report mineral dust and fly ash (with and without some volatiles), metallic particles, and black carbon as the most ice-active particles, measured with two different mass spectrometers behind the Ice-CVI. Cozic et al. (2008a) investigated black carbon enrichment with two particle soot absorption photometers simultaneously behind the Ice-CVI and a total inlet and by aerosol mass spectrometry (AMS) and single-particle mass spectrometer (measuring particles between $200 \mathrm{~nm}$ and $2 \mu \mathrm{m}$ ) behind the Ice- CVI during cloud events. They concluded, based on the enrichment, that black carbon is ice active.

In situ cloud measurements of IRs can be performed with an aircraft for pure ice clouds, like for cirrus clouds, with the use of a counterflow virtual impactor (CVI) (Ogren et al., 1985; Heintzenberg et al., 1996; Ström and Ohlsson, 1998; Twohy et al., 2003; Froyd et al., 2010; Cziczo and Froyd, 2014; Cziczo et al., 2017) and references therein). In situ IR sampling in mixed-phase cloud requires an extra step to separate ice crystals from droplets and has, therefore, up to now been restricted to ground-based measurements. A dedicated inlet system (Ice-CVI) was developed by Mertes et al. (2007) to sample freshly produced ice particles in mixedphase clouds and, after sublimating the ice, deliver the residuals (IRs) to connected sampling or analysing instruments. As described in Mertes et al. (2007), a residual particle can be interpreted as its original INP only when sampling small ice crystals. There are three reasons for this size restriction leading to sampling of rather young ice particles. The first reason is that only the small ice particles grow by water vapour diffusion; in contrast, larger ice particles could further grow by riming. Moreover, larger and older ice particles experience impaction scavenging by interstitial particles. Both processes add more aerosol particles to the ice crystal and thus the original INP cannot be identified any more after ice sublimation in the Ice-CVI. Last is the technical reason that larger ice particles would shatter and break up at the inner surfaces of the Ice-CVI sampling system.

The major aims of our paper are to improve the sampling approach and to study the variation in IRs in mixed-phase clouds. In contrast to previous work (Worringen et al., 2015; 
Ebert et al., 2011; Kamphus et al., 2010; Schmidt et al., 2017), IR and total aerosol were collected in parallel. This allows us to examine the ice nucleation efficiency of the various particle groups and to investigate the dependence on temperature, particle size, and air mass history.

\section{Experimental}

\subsection{Sampling}

In January-February 2017 an extensive field campaign was conducted by INUIT (Ice Nucleation Research Unit funded by the German Research Foundation, DFG) at the high-altitude research station Jungfraujoch in Switzerland (3580 ma.s.1.). The campaign lasted for 5 weeks with the aim to investigate IRs from mixed-phase clouds, which are considered to be the original true INPs. During mixedphase cloud events, IRs were separated from other cloud constituents like interstitial aerosol particles, supercooled droplets, and large ice aggregates by use of the Ice-CVI (Mertes et al., 2007). Total aerosol particles (interstitial particles and IRs) were sampled in parallel. Particles were sampled by the use of multi MINI cascade impactors with the same design as described in Ebert et al. (2016) and Schütze et al. (2017), but with the use of only one stage with a lower $50 \%$ cut-off diameter of approximately $0.1 \mu \mathrm{m}$ (aerodynamic). The multi MINI cascade impactor is equipped with purge flow and 5 min flushing of the system was always performed prior to sampling to avoid carryover of particles from previous samples. The particles were collected on boron substrates to allow detection of light elements including carbon (Choël et al., 2005; Ebert et al., 2016).

\subsection{Total aerosol sampling}

Total aerosol particles were sampled in parallel to IRs behind a heated inlet (Weingartner et al., 1999) to study IR enrichment and depletion, identify contaminants, and characterize the air masses present. Total aerosol samples were collected with a dilution set-up (Fig. 1) to match the longer sampling time (up to $5 \mathrm{~h}$ ) of the Ice-CVI. The dilution unit is built up by two valves to control the air stream in and out of the system, making it possible to send air through two filters to dilute the incoming aerosol flow. Without this dilution, due to the much higher concentration of total particles, these samples would be overloaded and not suited for single-particle analysis.

\subsection{Ice-CVI}

The Ice-CVI is a modified counterflow virtual impactor which can separate freshly formed ice particles in mixedphase clouds; for details see Mertes et al. (2007). The inlet consists of several components to separate: (a) large precipitating ice crystals $>50 \mu \mathrm{m}$ by the $90^{\circ}$ inlet, (b) large ice particles $>20 \mu \mathrm{m}$ with a virtual impactor, (c) supercooled droplets

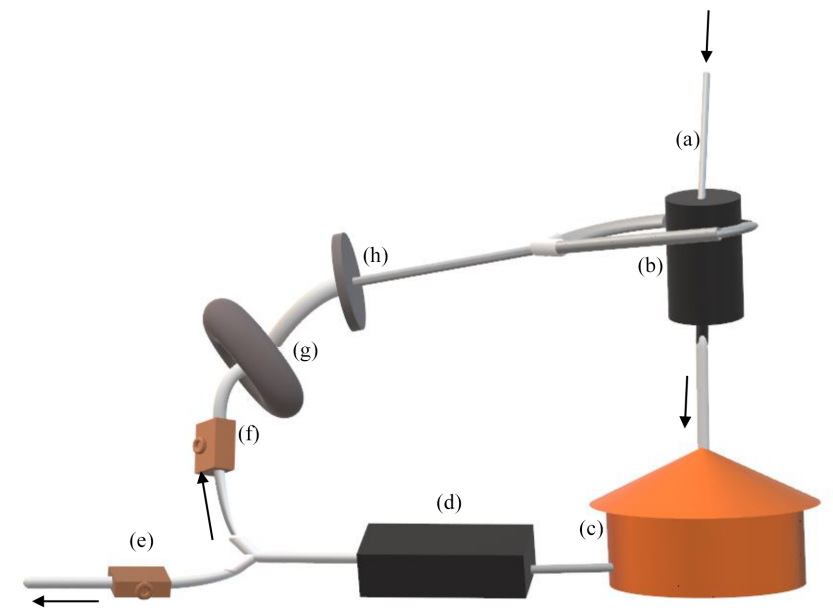

Figure 1. Illustration of the dilution unit behind the heated total inlet. (a) An inlet tube attached to the total inlet, (b) diluter, (c) multi MINI impactor, (d) pump, (e) valve to control outflow, (f) valve to control air going back in the system, (g) pre-filter (Whatman, Sigma-Aldrich), and (h) main filter (Millipore, Sigma-Aldrich). Arrows indicate the air flow direction.

$>5 \mu \mathrm{m}$ with two cold impaction plates where the droplets freeze and the ice crystals bounce off, and (d) interstitial particles $<5 \mu \mathrm{m}$, which are removed by a counterflow virtual impactor.

\subsection{Scanning electron microscopy}

Size, morphology, chemical composition, and mixing state of IRs and total aerosol particles were investigated by scanning electron microscopy using a FEI Quanta 400 ESEM FEG instrument (FEI, Eindhoven, the Netherlands) equipped with an energy-dispersive X-ray detector (Oxford, Oxfordshire, UK). All analyses were carried out manually, referred to as operator-controlled scanning electron microscopy (SEM) instrument, using an acceleration voltage of $15 \mathrm{kV}$ and a sample chamber pressure of around $1 \times 10^{-5} \mathrm{mbar}$. The multipoint feature "point\&ID" in the Oxford software Aztec (version $3.3 \mathrm{SP}$ ) was used for the operator-controlled singleparticle analysis. On each sample, about 500 particles were measured with $5 \mathrm{~s}$ of counting time for X-ray microanalysis. To ensure unbiased results, all particles in an image frame with an equivalent projected area diameter $\geq 100 \mathrm{~nm}$ were investigated. The particles were classified based on chemical composition, mixing state, morphology, and stability under the electron beam. Classification criteria and possible sources are given in Table 1. Particles that could not be assigned to any of the defined classes were grouped as "other". This group contains for example $\mathrm{Mg}$-rich, Zn-rich, and Agcontaining particles. Four groups are interpreted as contamination particles: pure salt, alumina, and $\mathrm{Cu}$-rich and $\mathrm{Ni}$-rich particles. 
Table 1. Classification criteria and possible sources/explanations for particle groups for both total aerosol and ice particle residuals.

\begin{tabular}{|c|c|c|c|}
\hline Group & Major elements & $\begin{array}{l}\text { Morphology/ } \\
\text { beam stability }\end{array}$ & Source/particle explanation \\
\hline Soot & $\mathrm{C}$ & $\begin{array}{l}\text { Chain-like or more com- } \\
\text { pact agglomerates of pri- } \\
\text { mary particles }\end{array}$ & Combustion, black carbon \\
\hline C-rich particles & $\mathrm{C}$ & No soot morphology & $\begin{array}{l}\text { Organic aerosol, biomass burning }{ }^{* *} \text {, } \\
\text { biological }^{* *}\end{array}$ \\
\hline $\begin{array}{l}\text { Complex secondary } \\
\text { particles }\end{array}$ & $\begin{array}{l}\text { No X-ray spectra or } \\
\text { S peak }\end{array}$ & $\begin{array}{l}\text { Most particles evaporating, } \\
\text { some relatively stable }\end{array}$ & $\begin{array}{l}\text { Sulfur-rich secondary organic aerosol; } \\
\text { might also contain a substantial fraction of } \\
\text { nitrates and other organics }\end{array}$ \\
\hline Aged - sea salt & $\begin{array}{l}\mathrm{Na}, \mathrm{S} \text { (sometimes small } \\
\text { amount of } \mathrm{Cl} \text { and } \mathrm{Mg} \text { ) }\end{array}$ & Relatively stable & $\begin{array}{l}\text { Marine aerosol, sea spray, might contain } \\
\text { organics }\end{array}$ \\
\hline Mixed - sea salt & $\begin{array}{l}\mathrm{Na}, \mathrm{S} \text { (sometimes small } \\
\text { amount of } \mathrm{Cl} \text { and } \mathrm{Mg} \text { ) } \\
+ \text { mineral composition }\end{array}$ & & $\begin{array}{l}\text { Marine aerosol mixed with mineral particles. } \\
\text { Might contain organics. }\end{array}$ \\
\hline Ca-rich particles & $\mathrm{Ca}, \mathrm{C}, \mathrm{O}$ & & $\begin{array}{l}\text { Mineral particles, calcium carbonates, } \\
\text { e.g. calcite }\end{array}$ \\
\hline Ca sulfate & $\mathrm{Ca}, \mathrm{S}, \mathrm{O}$ & & Mineral particles, e.g. gypsum and anhydrite \\
\hline Silica & $\mathrm{Si}, \mathrm{O}$ & & Mineral particles, e.g. quartz \\
\hline Aluminosilicate & $\mathrm{Al}, \mathrm{Si}, \mathrm{O}$ & & Mineral particles, e.g. kaolinite \\
\hline Fe aluminosilicate & $\mathrm{Al}, \mathrm{Si}, \mathrm{Fe}, \mathrm{O}$ & & Mineral particles, e.g. almandine \\
\hline Other aluminosilicates & $\begin{array}{l}\text { Variable amounts of } \mathrm{Na} \\
\mathrm{K}, \mathrm{Ca}, \mathrm{Si}, \mathrm{Al}, \mathrm{O}, \mathrm{Ti} \text {, and } \\
\mathrm{Fe}\end{array}$ & & $\begin{array}{l}\text { Mineral particles, e.g. feldspars, illite, and } \\
\text { smectite (montmorillonite) }\end{array}$ \\
\hline Metal/metal oxides & $\begin{array}{l}\mathrm{Fe}, \mathrm{O} \text { or } \mathrm{Ti}, \mathrm{O} \text { or } \mathrm{Fe}, \mathrm{Cr} \text {, } \\
\mathrm{Mn}\end{array}$ & $\begin{array}{l}\text { Fly ash was detected as } \\
\text { spherical particles }\end{array}$ & $\begin{array}{l}\text { Mineral particles like hematite, magnetite, } \\
\text { and rutile, or steel particles (alloys) }\end{array}$ \\
\hline $\mathrm{Pb}$-rich particles & $\mathrm{Pb}$, or $\mathrm{Pb}, \mathrm{Cl}$ & $\begin{array}{l}\text { Single particle or inclusions } \\
\text { within particle }\end{array}$ & $\begin{array}{l}\text { Helicopters and small aircrafts, previously } \\
\text { reported at Jungfraujoch }\end{array}$ \\
\hline Other & $\begin{array}{l}\text { Particles which do not } \\
\text { meet the classification } \\
\text { criteria above }\end{array}$ & & \\
\hline Alumina* & $\mathrm{Al}, \mathrm{O}$ & & Artefact, Ice-CVI \\
\hline Ni-rich particles* & $\mathrm{Ni}$ & & Artefact, Ice-CVI \\
\hline Cu-rich particles* & $\mathrm{Cu}$ & & Artefact, particle substrate \\
\hline Pure salt* & $\mathrm{Na}, \mathrm{Cl}$ & & $\begin{array}{l}\text { Artefact, hypothesized from secondary ice } \\
\text { processes, e.g. crystal break-up, marine } \\
\text { origin** }^{* *}\end{array}$ \\
\hline
\end{tabular}

${ }^{*}$ Most likely contamination. ${ }^{* *}$ Uncertain origin because the chemical characterization and/or morphology was not typical for this particle group.

\subsection{Sampling days, meteorology, and footprint plots}

During 7 days, 10 Ice-CVI samples were taken in clouds at site temperatures between -10 and $-18^{\circ} \mathrm{C}$. Sampling day, time, and site temperatures are presented in Fig. 2 and as a table in the electronic Supplement (Table S1). Temperatures were measured at the station and can differ from the onset ice nucleation temperature of the particles depending on where in the mixed phase cloud nucleation occurred. Six parallel total aerosol samples were successfully collected. The 


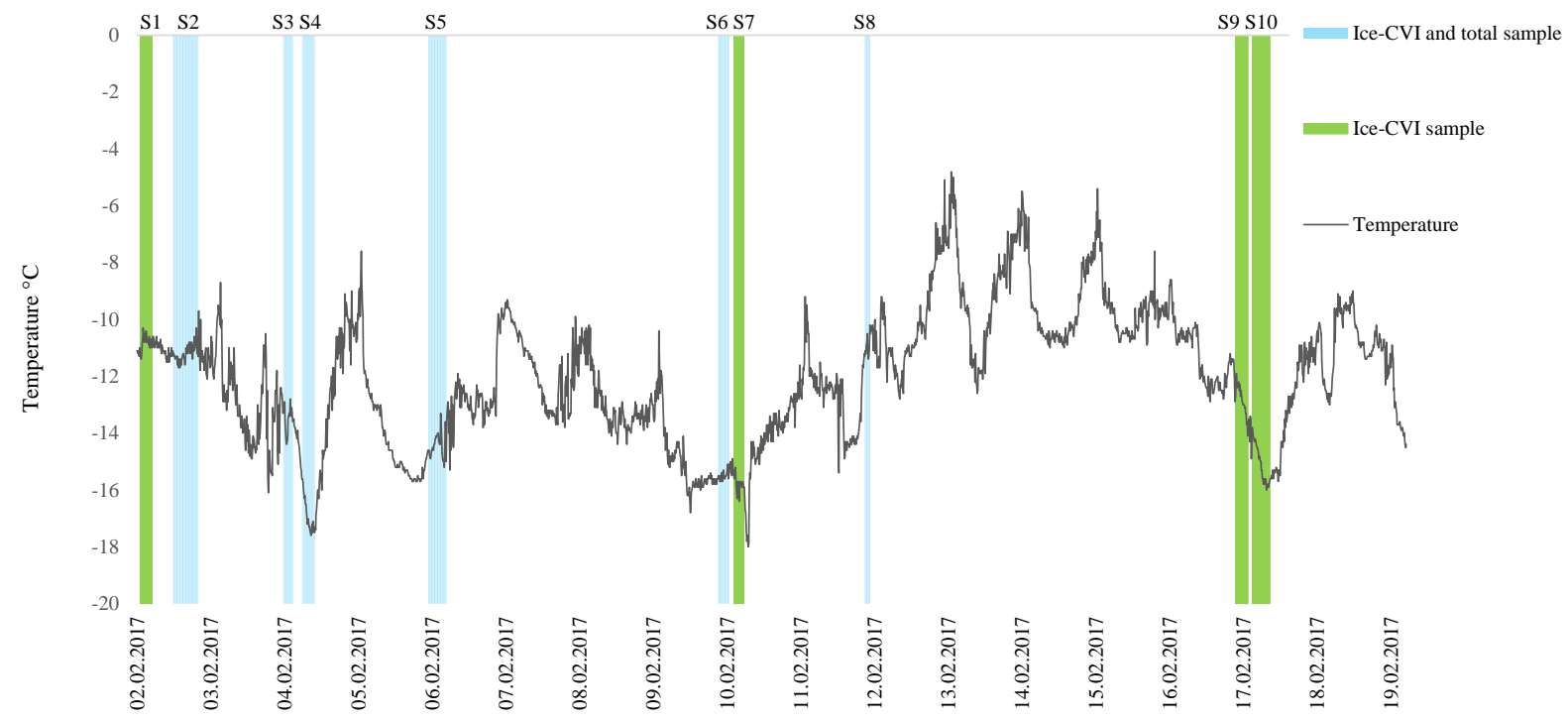

Figure 2. Temperature $\left({ }^{\circ} \mathrm{C}\right)$ and sampling times in February 2017 behind Ice-CVI and total inlet. Sample numbers are given above the bars. Blue bars indicate sampling periods with parallel samples, and green bars periods for which only IR samples could be analysed. Temperature data were received from the Federal Office of Meteorology and Climatology (MeteoSwiss; https://www.meteoswiss.admin.ch, last access: 17 October 2017 ).

other four total samples are either overloaded or do not have enough particles on the substrate.

During the whole campaign, north-easterly and southwesterly winds were the dominating local wind directions in accordance with the topography at Jungfraujoch. Footprint plots, showing the probable air mass residence time at the surface, were calculated with the FLEXPART model (Stohl et al., 1998, 2005; Stohl and Thomson, 1999; Seibert and Frank, 2004). These plots are calculated with 10-day back trajectories and a potential emission sensitivity to determine the probable emission region of the particles arriving at Jungfraujoch. Wind roses and footprint plots are presented in Fig. 3.

\subsection{Methodological problems}

\subsubsection{Sampling artefacts}

The observed alumina, pure salt, and Ni-rich and $\mathrm{Cu}$-rich particles are regarded as sampling artefacts. The IR samples are heavily loaded with artefacts $(40 \%-78 \%$ of the particles alumina, Ni-rich particles, and pure salt) easily characterized and removed in further analysis. The $\mathrm{Cu}$-rich particles are a part of the substrates and can in principle be found in both IR samples and total aerosol samples. Alumina particles are found in all IR samples at relative high number abundances between $25 \%$ and $70 \%$, despite the fact that the Ice-CVI was coated before the present campaign with Ni to avoid this contamination. The relative abundance of alumina particles in IR samples is higher in our campaign compared to two previous campaigns at Jungfraujoch using the same instrumentation but without the Ni coating of the Ice-CVI (Ebert et al., 2011; Worringen et al., 2015). This might be explained by the fact that we only focused on the sub-micrometer particles and/ or the difference in meteorology, sample time, and particle load all influencing the relative composition of contamination particles. In contrast to previous work, we sampled IR and total aerosol in parallel to be able to clearly distinguish instrumental artefacts from IRs. As we did not detect a single alumina particle in total aerosol samples, this particle group is regarded as contamination. Alumina particles are easily recognized and were subtracted from the real IRs. Nevertheless, their presence helped substantially to locate the impaction spot on the boron substrates.

Secondary ice processes can produce ice crystals in the critical size range selected by the Ice-CVI. The low temperature during sampling does not support the Hallett-Mossop process (Hallett and Mossop, 1974) regarding rime splintering, but other secondary processes producing ice crystals like ice-crystal break-up, blown snow, or crystal-crystal collisions in the critical size range are plausible (Mertes et al., 2007). We hypothesize that pure salt is an artefact due to sampling of the mentioned secondary ice production processes in clouds. The presence of sodium and chloride in ice crystals previously acting as cloud condensation nuclei can later form solid $\mathrm{NaCl}$ in line or on the substrate after evaporation of water. This hypothesis is inconclusive because pure salt is not observed in the total aerosol fraction, where only aged and mixed salt are present. This might be explained by evaporation of ice crystals in the heated inlet and the longer sampling line and the relatively low number concentration of these particles compared to the dominating groups (soot and complex 
(a)
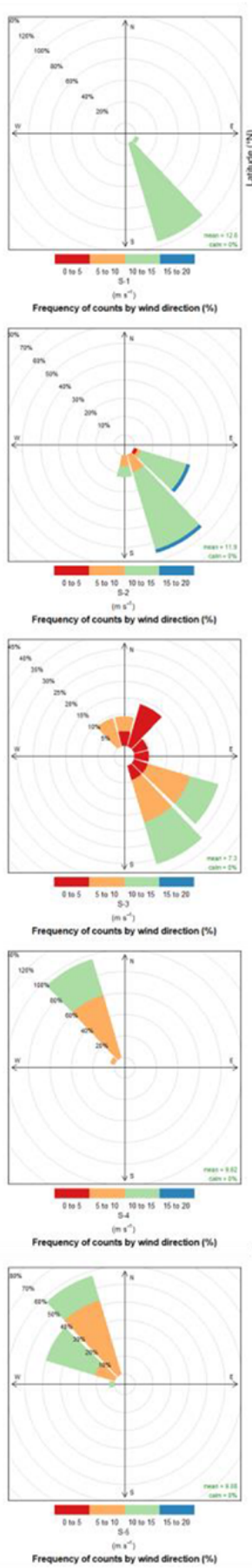

(b)
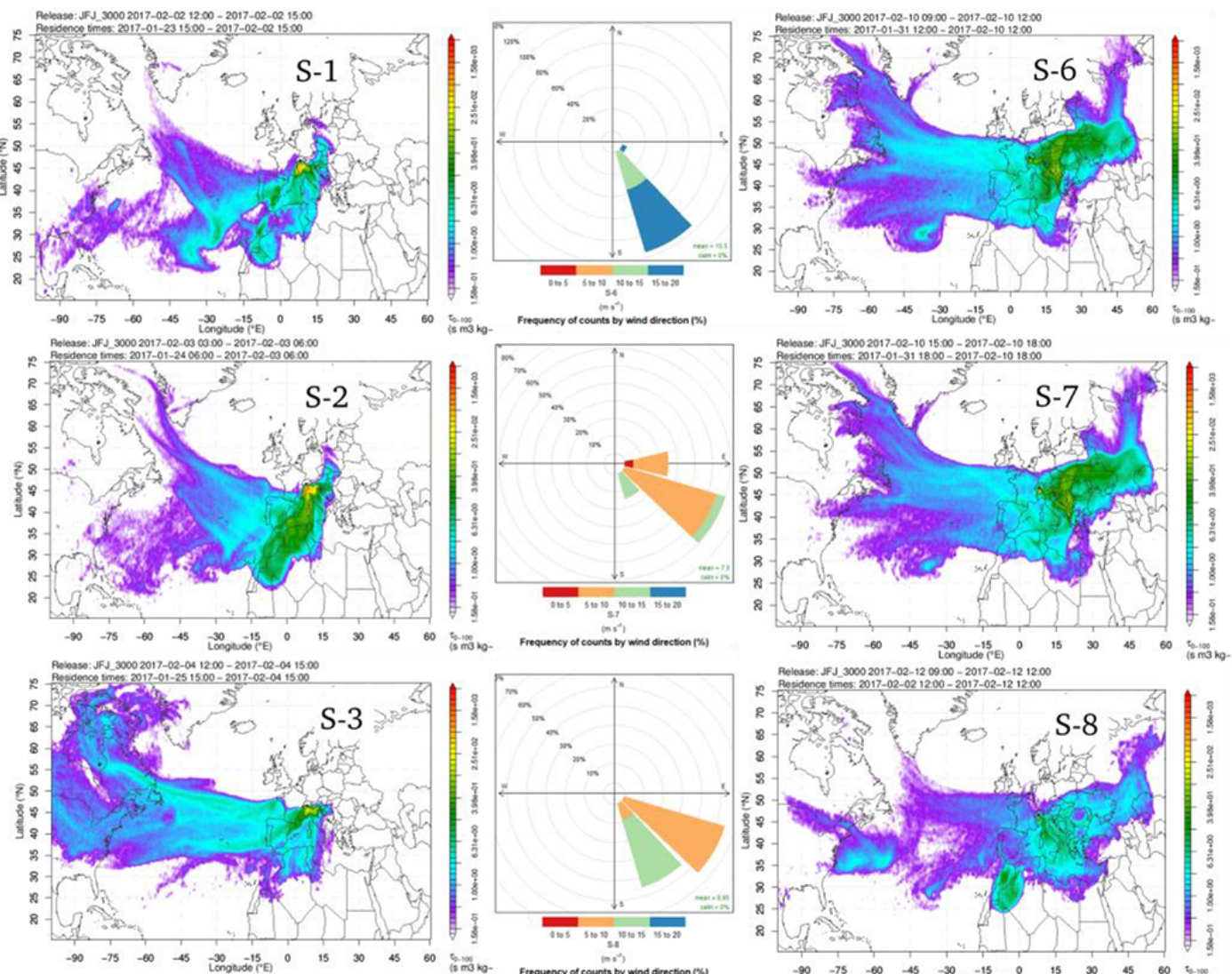

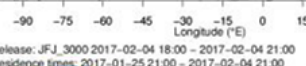
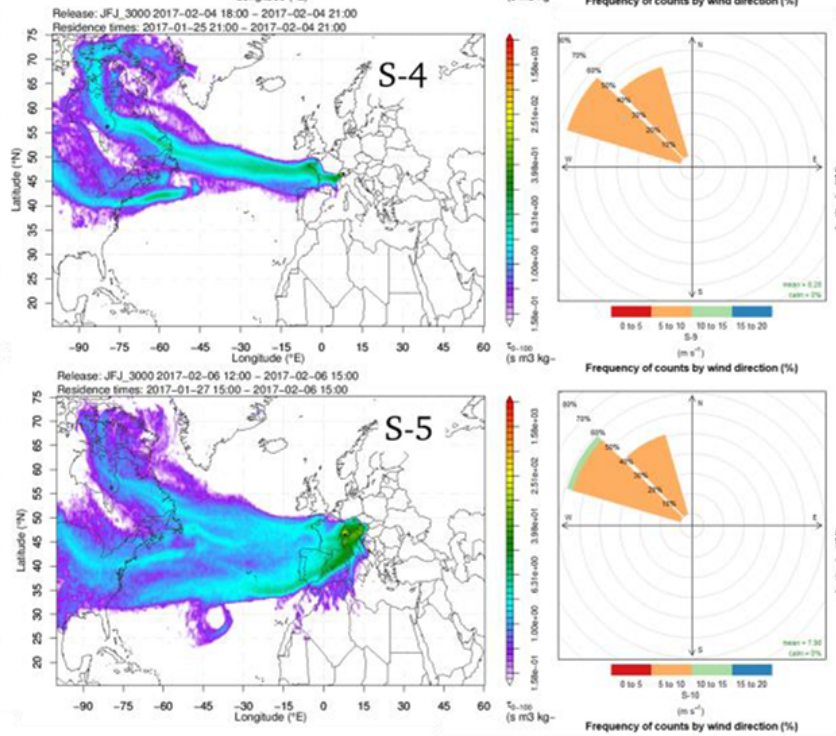
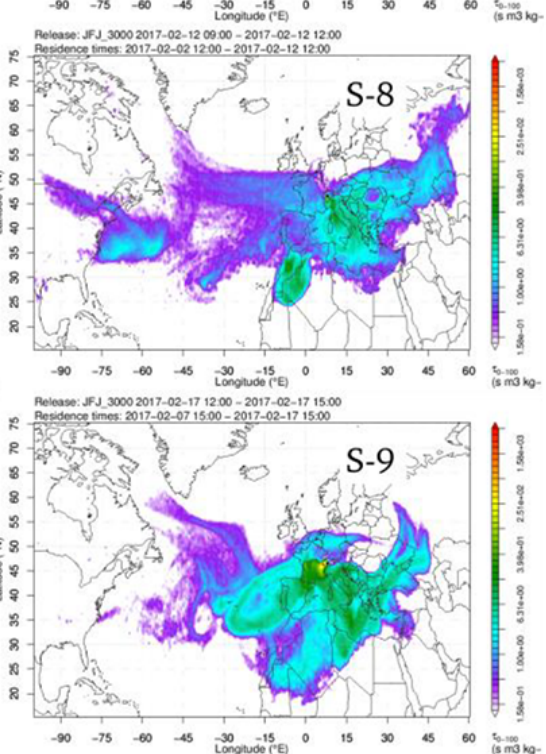

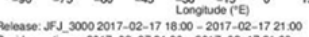

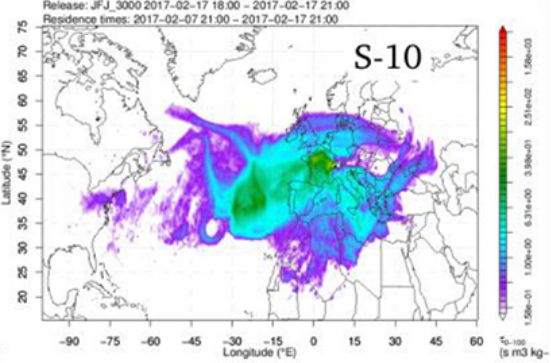

Figure 3. Wind rose (a) and footprint plots (b) calculated with the FLEXPART model, http://lagrange.empa.ch/FLEXPART_browser/ (last access: 17 January 2018) (Stohl et al., 1998, 2005; Stohl and Thomson, 1999; Seibert and Frank, 2004). Horizontal wind direction and speed were obtained from the Federal Office of Meteorology and Climatology (MeteoSwiss; https://www.meteoswiss.admin.ch, last access: 17 October 2017). 
secondary particles) in the total aerosol samples. It should be mentioned here that sea salt was considered to be an artefact in the IR fraction by Worringen et al. (2015).

A few Ni-rich particles ( $1 \%-7 \%$ relative by number) were encountered in the IR fraction but not in the total aerosol. The Ni-rich particles most likely stem from the Ni coating of some parts of the Ice-CVI. The few $\mathrm{Cu}$-rich particles found, in both total aerosol and the IR samples, are from the boron substrate in which boron is embedded in copper.

\subsubsection{Accuracy of particle group abundance}

Accuracy of the particle group abundance depends on three different factors: (1) separation of IR from the rest of the aerosol particles by the Ice-CVI and deposition losses behind both inlets, (2) detection of particles in SEM, and (3) the classification procedure. Sampling issues like abrasion, deposition losses, and ice crystal break-up may occur in the Ice-CVI (Mertes et al., 2007). Abrasion particles were easily recognized as discussed in the previous paragraph. Sampling of secondary ice may have led to the relatively high abundance $(\sim 2 \%-28 \%)$ of pure salt particles in the IR fraction discussed in the previous paragraph. As we regard pure salt particles as an artefact, they are not included in the sea-saltcontaining particle group. Deposition loss can generally not be excluded. Three of the total aerosol samples (S-3b, S-4b, and $\mathrm{S}-6 \mathrm{~b}$ ) are sampled under conditions in which the concentration (measured with condensation particle counters) of the total inlet was lower than the interstitial inlet. There are two possible explanations for this: deposition loss in the total aerosol inlet and/or a leak in the interstitial inlet. The relative abundance of the different particle groups in these samples is however comparable to previous findings at Jungfraujoch (Cozic et al., 2008b; Kamphus et al., 2010; Fröhlich et al., 2015). A possible deposition loss leading to systematic bias in the concentration measurements does not seem to change the relative abundance of the different particle groups. Our conclusions are thus not affected as we do not discuss number concentrations.

For most particle groups we do not expect to have significant detection artefacts in SEM. These particle groups are detected with high efficiency, in both the total aerosol as well as the IR fraction. However, C-rich particles and soot may be interchanged in total aerosol samples because the image quality can be reduced by evaporating complex secondary particles, leading to less efficient detection of carbonaceous species, which have a low contrast in SEM images. Usually, evaporation of complex secondary particles is not a problem because the particles are observed at the start of analysis. Nevertheless, in one sample, complex secondary particles were lost prior to observation because this sample was erroneously left in the chamber for a longer time before it was analysed. However, these effects seem to be small because we have observed an abundance of carbonaceous particles and complex secondary aerosol particles (in total aerosol) comparable to in previous work (Cozic et al., 2008b).

The classification criteria used (Table 1) may lead to problems for small (below approximately $150 \mathrm{~nm}$ equivalent projected area diameter) carbonaceous particles. Due to the limited lateral resolution of the instrument, the typical morphology of soot may not be recognized for small particles. In this case, soot would be misclassified as C-rich particles. Still, the sum of both particle groups should be accurate. However, this problem is only significant for the total aerosol samples because evaporating secondary aerosol in these samples leads to deterioration of the image quality. Misclassification of soot as C-rich particles would imply that soot is even more depleted in the IR fraction.

\subsection{Statistical analysis}

To calculate enrichment and depletion of the different particle groups in the IR fraction relative to total aerosol, all particle group abundances are normalized to the abundance of the aluminosilicate group. We have chosen this group as a reference as it has the highest relative abundance in both the IR samples and the total aerosol. We do not show a simple ratio of proportions (e.g. proportion of aluminosilicates in IRs divided by proportion of this group in total aerosol) because the proportion is constrained to values between 0 and 1. This is generally referred to as closed data (Aitchison, 2003; Van den Boogaart and Tolosana-Delgado, 2013) and implies that only ratios of two groups can be interpreted (i.e. not the proportion of one group alone). Furthermore, we do not discuss differences in proportions between IR and total aerosol as in Ebert et al. (2011), as this difference is strongly dependent on the relative abundance of a particle group. To overcome these problems, only aluminosilicate normalized particle group abundances are used to quantify enrichment/depletion of a particle group in the IR fraction. This measure is termed odds ratio in the statistical literature.

The odds ratios (OR) is calculated in the following way:

$\mathrm{OR}_{\mathrm{i}}=\frac{\left(\frac{n_{\mathrm{i}}}{n_{\mathrm{AlSi}}}\right)_{\mathrm{IR}}}{\left(\frac{n_{\mathrm{i}}}{n_{\mathrm{AlSi}}}\right)_{\text {total }}}$,

with $n_{\mathrm{i}}$ the absolute number of particles in particle group $\mathrm{i}$, $n_{\mathrm{AlSi}}$ the absolute number of particles in the group of aluminosilicates in both IR and the total aerosol fraction. For particle groups which did not contain a single particle, one particle (which is the detection limit) was added to the respective group in order to calculate an odds ratio. For these groups the odds ratios shown in Fig. 8 represent an upper or lower limit. The odds ratios represent enrichment or depletion of a particle group normalized to aluminosilicates when the IR fraction is compared to the total aerosol. Enrichment relative to aluminosilicates is discussed for each group that is present in the IR. The two groups of complex secondary particles and soot are interpreted as depleted because these 
particles are not found in the IR fraction. These two particle groups are hence depleted compared to aluminosilicates and absolutely depleted compared to total aerosol.

The Fisher test was applied to estimate confidence intervals for the odds ratio and was calculated with RStudio (RStudioTeam, 2016). Figures 5, 7, and 8 are plotted in RStudio with the package "ggplot2" (Wickham, 2009). Wind roses (Fig. 3) were plotted with the RStudio package "openair" (Carlslaw and Ropkins, 2012).

\section{Results}

\subsection{Total aerosol}

Particle groups observed in the total aerosol samples include complex secondary particles, soot, C-rich particles, Ca-rich particles, Ca sulfates, silica, aluminosilicates, Fe aluminosilicates, other aluminosilicates, metal/metal oxide, sea-saltcontaining particles (aged and mixed), and other particles (Fig. 4).

A few fly ash particles were detected in the metal/metal oxides group. In addition, one group of artefact particles $(\mathrm{Cu}-$ rich particles) originating from the substrate was found and excluded from further analysis. Four of the six samples are dominated by secondary aerosol, which consists of sulfates and highly instable particles (under vacuum and/or electron bombardment) for which no X-ray spectrum could be obtained. Still, remains of these particles are easily seen in the secondary electron images. The highly instable particles are classified based on the fact that they evaporated during the operator-controlled X-ray analysis. In contrast to the IR fraction, we observed two groups of carbonaceous particles. Carbon-dominated particles without typical morphology are classified as C-rich particles (Fig. S1). Chain-like or more compacted agglomerates of spherical primary carbonaceous particles are interpreted as soot in accordance with previous literature, e.g. Wentzel et al. (2003), Buseck et al. (2014), and Weinbruch et al. (2018). Sample S-2b was taken during night-time and consists of two separate samples directly taken one after the other (for $3 \mathrm{~h}$ each). The unusually high abundance of carbonaceous particles within this sample most likely results from urban/industrial sources of the Po Valley seen in the footprint plot (Fig. 3). Sample S-5b shows a high relative abundance of mineral particles, which may be the result of having lost complex secondary particles in the instrument, as this sample was exposed to the vacuum of the electron microscope for a much longer time than the other samples.

Most of the total aerosol particles have a geometric diameter below $500 \mathrm{~nm}$ (Fig. 5). The mineral groups of aluminosilicates, Fe aluminosilicates, and other aluminosilicates are somewhat larger than the rest of the particle groups. The size distribution ( $\mathrm{dNd} \log \mathrm{D}_{\mathrm{p}}$ vs. particle diameter) is shown in the electronic Supplement (Fig. S3).

\subsection{Ice particle residuals}

The following particle groups were observed in the IR samples (Fig. 6): minerals (silica, aluminosilicates, Fe aluminosilicates, other aluminosilicates, Ca sulfates, and Ca-rich particles), sea-salt-containing particles (aged and mixed salt), $\mathrm{C}$-rich particles, $\mathrm{Pb}$-rich particles, metal/metal oxide, and other particles. In addition, four groups of sampling artefacts were found: pure salt, alumina, and Ni-rich and $\mathrm{Cu}$-rich particles. The sampling artefacts are regarded as contamination (see Sect. 2.6.) and are thus not included in the figures. Composition including contamination particles is given in the electronic Supplement (Fig. S5).

Mineral particles are of highest relative abundance (between $60 \%$ and $90 \%$ by number) in all samples (Fig. 6), and mainly consist of silica, aluminosilicates, and other aluminosilicates, as well as smaller fractions of Fe aluminosilicates, Ca sulfates, and Ca-rich particles. A small percentage ( $\leq 7 \%$ by number) of $\mathrm{Pb}$-rich particles $-\mathrm{PbCl}$ or particles containing heterogeneous $\mathrm{Pb}$ inclusions - are found in eight of the samples. Sea-salt-containing particles are present in all samples in variable amounts of up to $12 \%$. The C-rich particles observed in the IR fraction can be excluded from soot because they do not show the typical morphology of chain-like or more compacted agglomerates of primary particles (see Fig. S1). Instead, these particles are most probably organic particles. The group of metal/metal oxide particles includes Fe oxides/hydroxides, Ti oxides, and steel particles ( $\mathrm{Fe}, \mathrm{Cr}$, Mn alloys).

Most IRs have an equivalent projected area diameter below $500 \mathrm{~nm}$ (Fig. 7). The groups of Fe aluminosilicates and other aluminosilicates are somewhat larger and show a higher variation than the rest of the particle groups. The size distribution $\left(\mathrm{dNd} \log \mathrm{D}_{\mathrm{p}}\right.$ vs. particle diameter) is shown in the electronic Supplement in Fig. S4.

\subsection{IR vs. total aerosol}

For six sample pairs (simultaneous sampling of total aerosol and IR) the enrichment or depletion of the particle groups compared to aluminosilicates is shown in Fig. 8 as the odds ratio. Complex secondary particles and soot are always strongly depleted in the IR fraction, as not a single particle of both groups was observed as IR. An upper limit for the depletion relative to aluminosilicates can be obtained by setting the number of particles in the IR fraction for both groups equal to 1 (the detection limit). With this assumption it can be seen that soot is depleted in the IR fraction relative to aluminosilicates by at least a factor of 700 and secondary aerosol particles by a factor of at least 4200 . Both particle groups are also depleted in the IR fraction relative to total aerosol. $\mathrm{C}$-rich particles are less enriched in the IR fraction than aluminosilicates by a factor of approximately 20 .

$\mathrm{Pb}$-rich particles and other aluminosilicates are enriched (relative to aluminosilicates) within the IR fraction. However, 


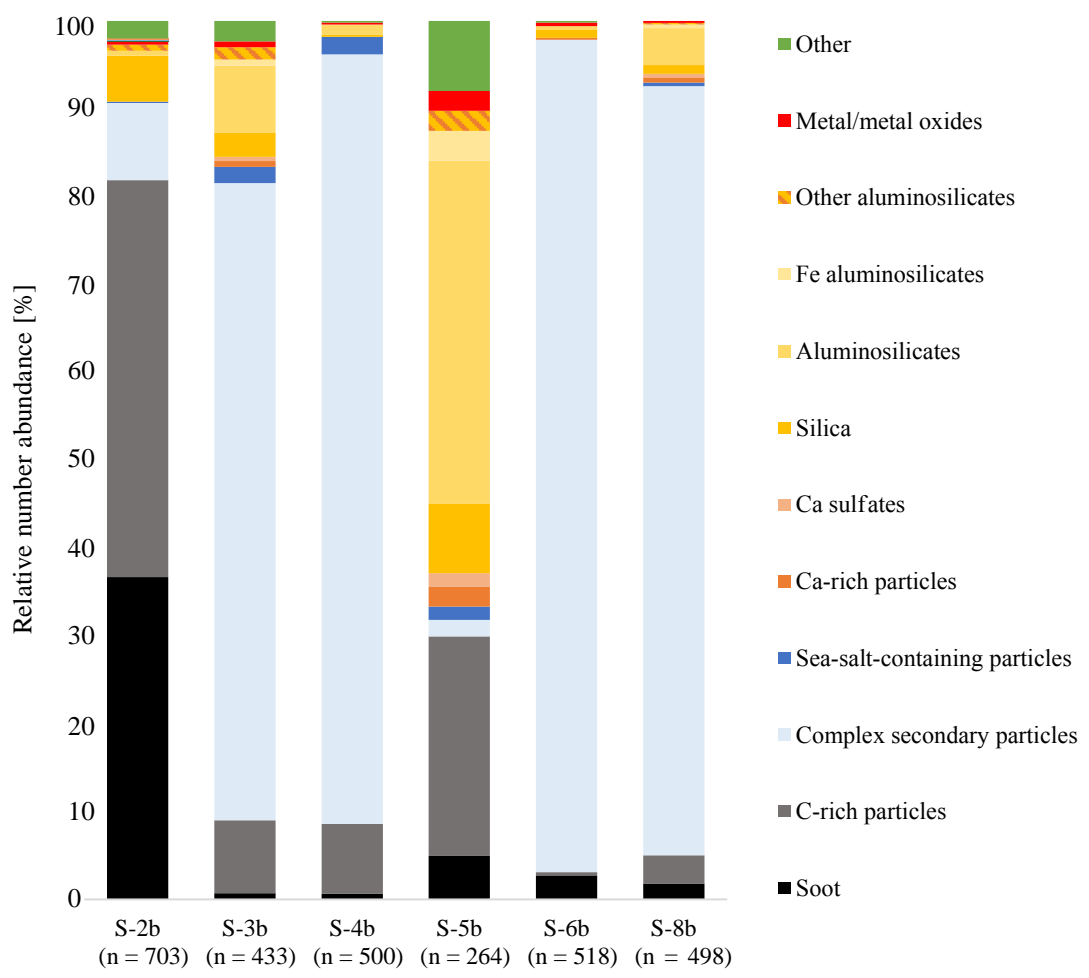

Figure 4. Relative number abundance of the different particle groups within total aerosol samples. Sample S-2b shows a combustion event with air mass history from the Po Valley, and sample S-5b is influenced by an analytical artefact from particle loss of volatile particles.

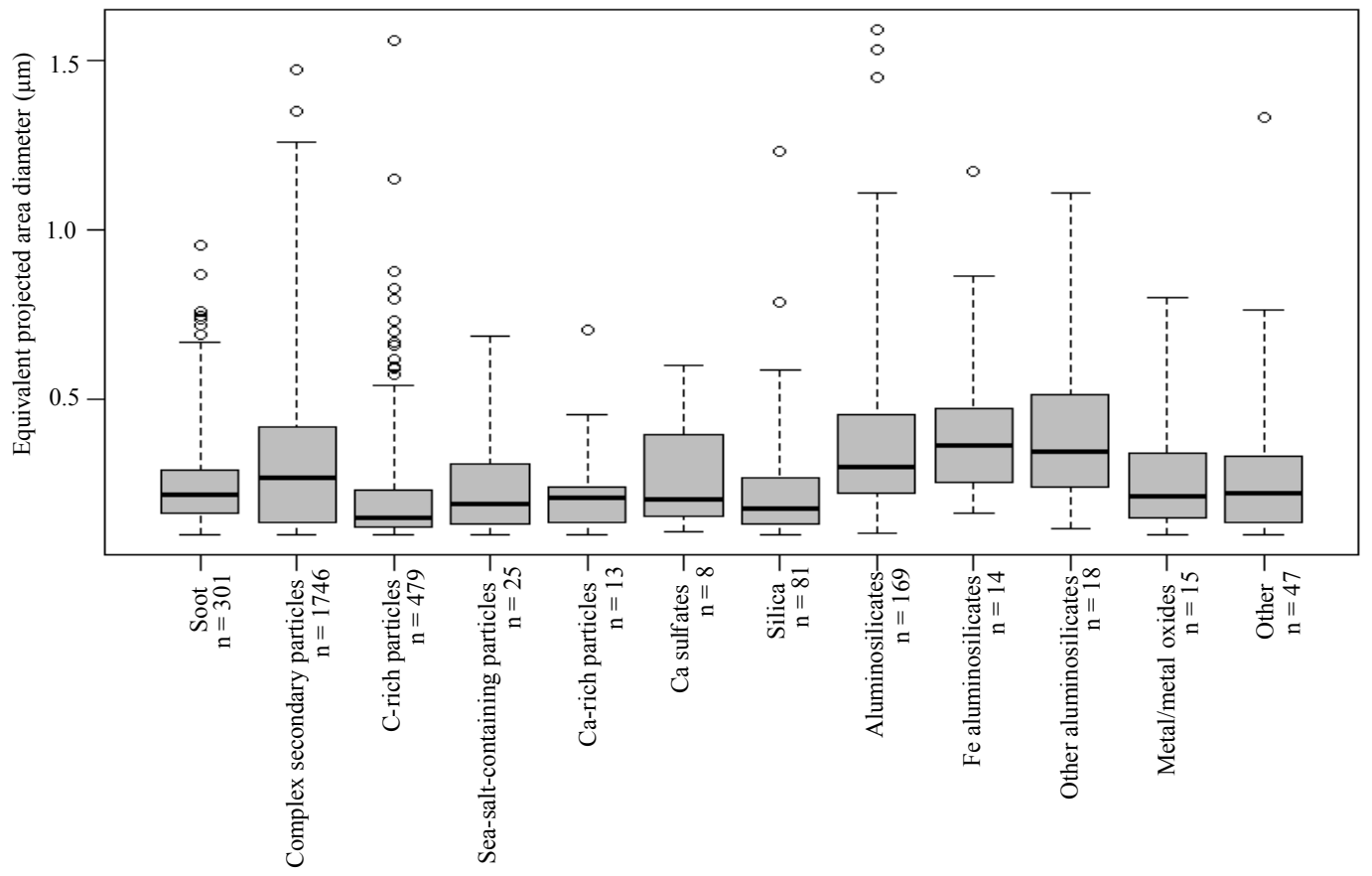

Figure 5. Size of total aerosol particles. 


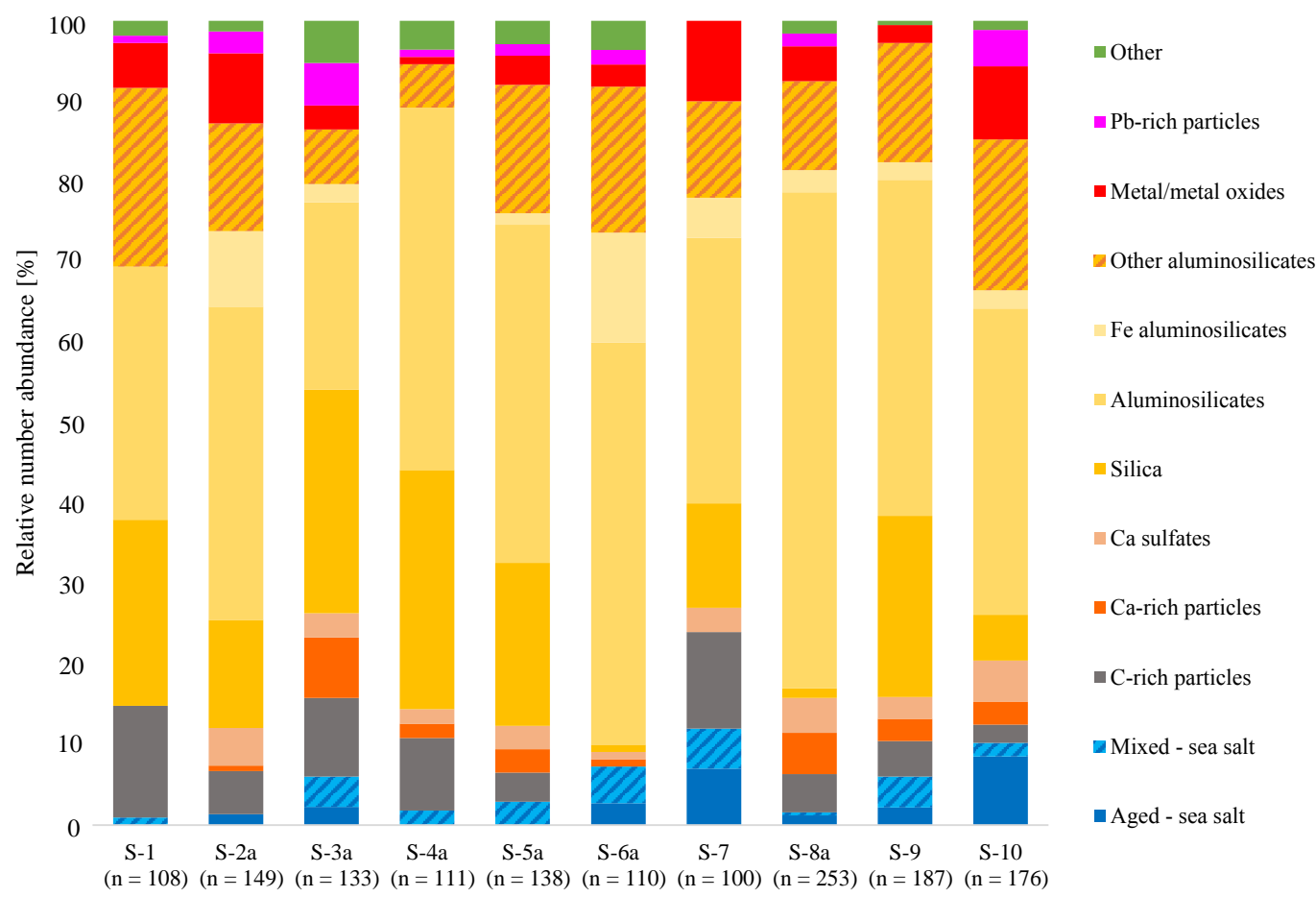

Figure 6. Relative number abundance of the different particle groups of IR sampled in mixed-phase clouds at site temperatures between -10 and $-18{ }^{\circ} \mathrm{C}$. Sampling artefacts (pure salt, alumina, and Ni-rich and $\mathrm{Cu}$-rich particles) are not shown.

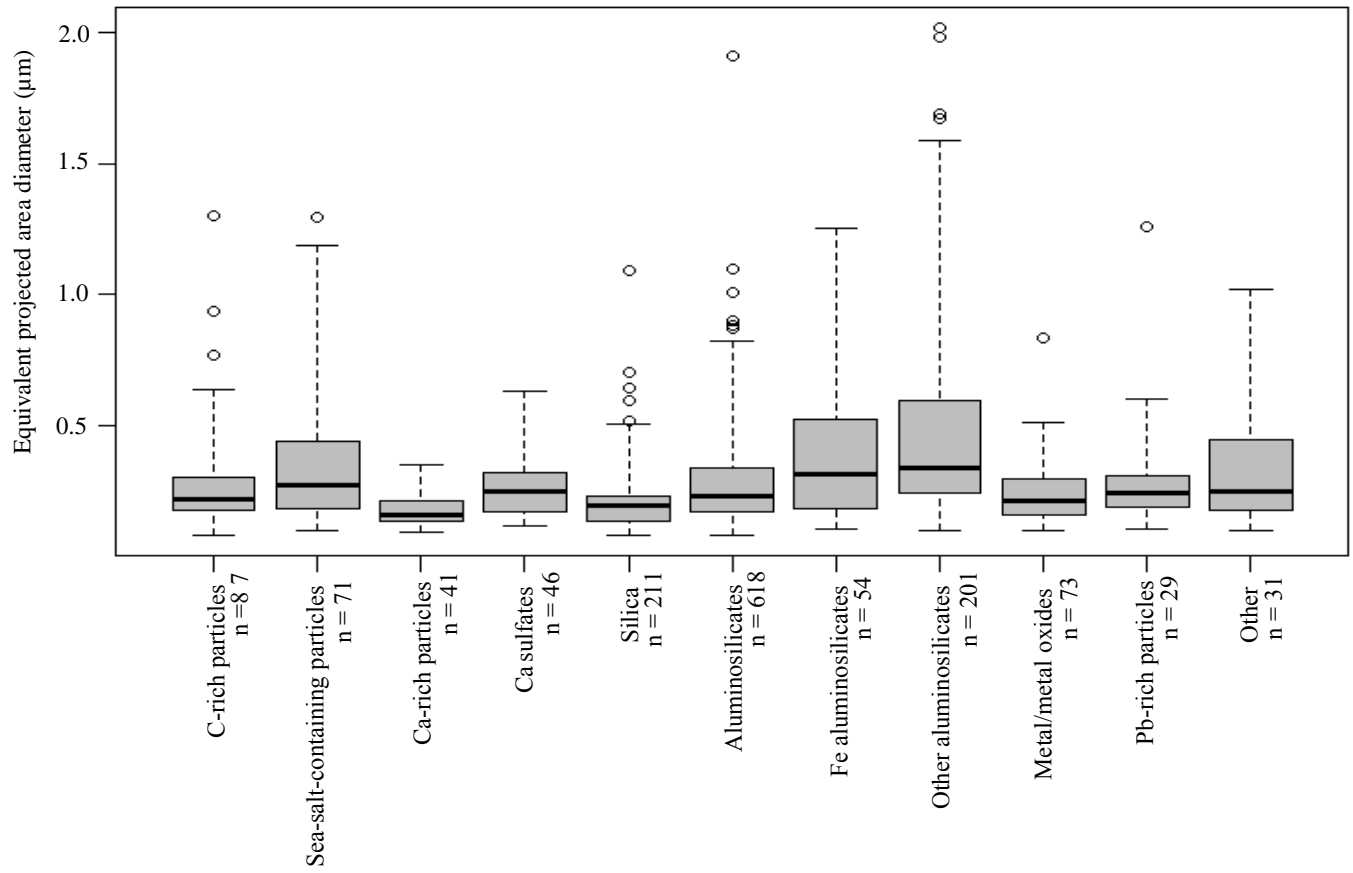

Figure 7. Size of IRs. Three outliers of other aluminosilicates are shown $(2.7,2.9$, and $3.4 \mu \mathrm{m})$. 


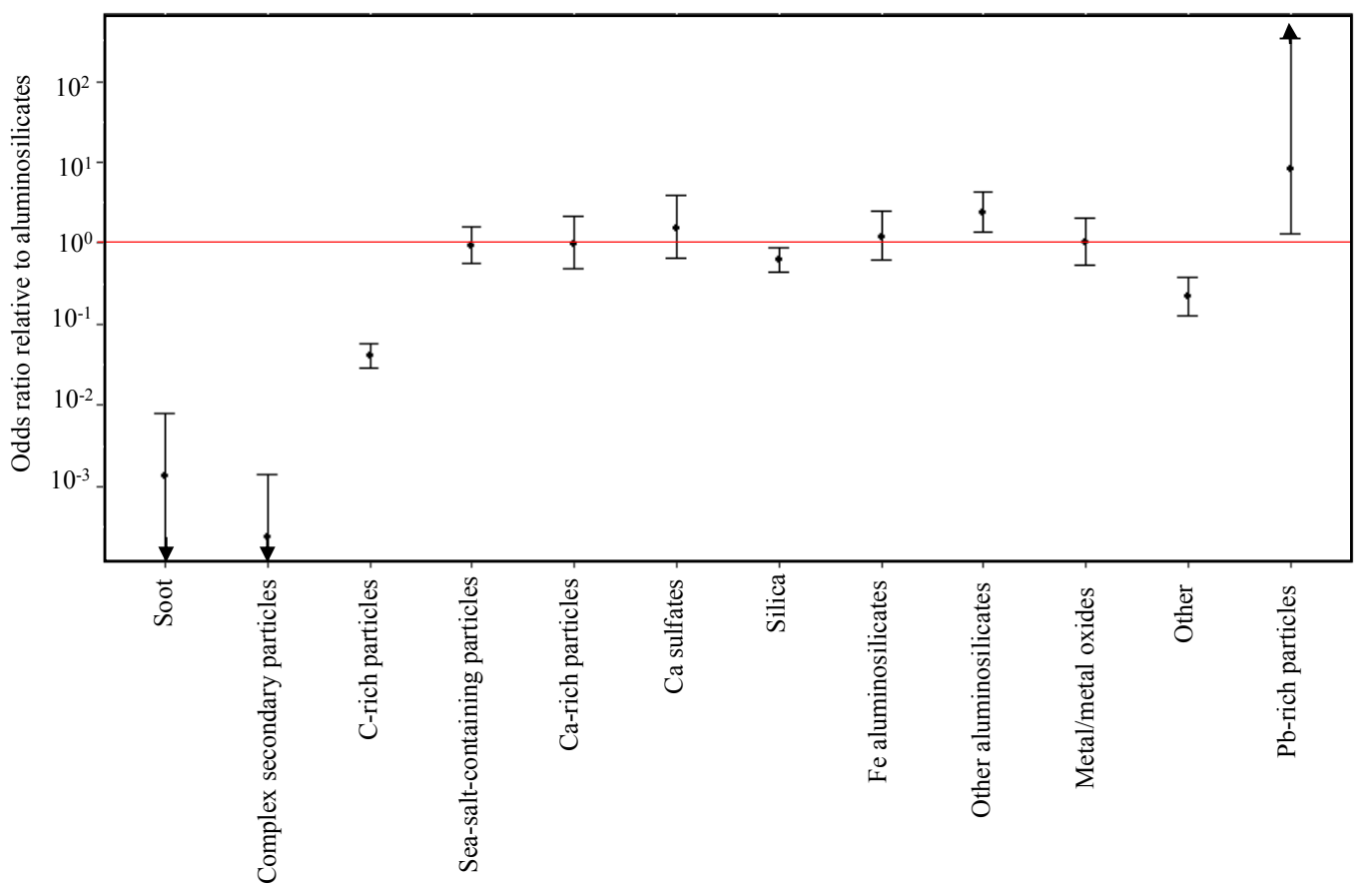

Figure 8. Enrichment or depletion of the different particle groups within the IR fraction expressed as the odds ratio (see text for details). The $95 \%$ confidence interval (CI) of the odds ratio is shown as error bars. For soot and complex secondary particles the lower limit of the CI, and for $\mathrm{Pb}$-rich particles the upper limit of the $\mathrm{CI}$, cannot be defined precisely due to counting statistics. Thus they are marked by arrows.

the enrichment factor has large uncertainties due to counting statistics. The remaining particle groups are, within counting error, enriched similarly in the IR fraction to aluminosilicates (for this latter group the odd ratio is 1 per definition).

\section{Discussion}

The major finding of our paper is that sea-salt-containing particles, Ca-rich particles, Ca sulfates, silica, Fe aluminosilicates, and metal/metal oxides are ice active similar to aluminosilicates at Jungfraujoch in warm mixed-phase clouds $\left(-10\right.$ to $\left.-18^{\circ} \mathrm{C}\right)$. Other aluminosilicates and the $\mathrm{Pb}$-rich particles seem to be even more ice active as aluminosilicates. In contrast, soot and complex secondary particles are strongly depleted (compared to aluminosilicates and absolutely compared to total aerosol) in the ice residuals. C-rich particles are less enriched than aluminosilicates by a factor of approximately 20. Thus, it is concluded that their ice nucleation ability under these conditions is significantly lower. The ice nucleation activities of the different particle groups are discussed in Sect. 4.2.

\subsection{Composition of total aerosol}

Four of the six total aerosol samples are dominated by complex secondary particles (Fig. 4), which seems to be typical for Jungfraujoch (Cozic et al., 2008b; Fröhlich et al., 2015).
Two samples (S-2b and S-5b) have a different composition (Fig. 4). The first sample (S-2b) shows a higher carbonaceous fraction, and the second sample (S-5b) a higher fraction of mineral particles and C-rich particles. The high soot and Crich particle abundance of the first sample may be explained by footprint plots showing that the air mass had a longer surface residence time over the Po Valley (Italy), which is an urban/industrial area with abundant sources of carbonaceous particles. The potential artefact in the second sample does not influence the enrichment factor for all other particle groups. The odds ratio of complex secondary particles shown in Fig. 8 will merely be somewhat lower. Our general conclusion that complex secondary particles are inefficient ice nuclei under the investigated conditions is not changed.

Most particles of the total aerosol have sizes below approximately $1 \mu \mathrm{m}$, which is in good agreement with Herrmann et al. (2015).

Overall, our total aerosol samples consist of complex secondary particles ( $60 \%$ by number) and C-rich particles $(16 \%)$, soot $(10 \%)$, and mineral particles $(14 \%)$. This composition is similar to previous findings at Jungfraujoch during winter. According to Cozic et al. (2008b) the total aerosol is dominated by organic matter and secondary aerosol $(87 \%$ by mass), with smaller contributions of black carbon (4\%) and a non-determined mass (reported as "assumed to be composed of insoluble compounds such as silicate from mineral dust") fraction (9\%). It was also shown by Kamphus et al. (2010) 
that the main components of the ambient aerosol at Jungfraujoch in winter (2007) are sulfate and organics, and only a small fraction (between $1 \%$ and $17 \%$ ) is classified as mineral particles.

With respect to ice nucleation, mineral dust particles are of the most importance (see Sect. 4.2.). Aluminosilicates are the most abundant group of mineral particles in the total aerosol with almost twice the amount of silica. This fits well to the distribution of different minerals in soils presented by Hoose et al. (2008) in which kaolinite and illite show a higher abundance than calcite and quartz in the clay fraction worldwide. Other aluminosilicates and $\mathrm{Ca}$-rich particles are present in four of the six samples at a low number concentration (1-2\%). Ca-containing particles at Jungfraujoch were also found by Cozic et al. (2008b), albeit mainly in the coarse mode.

The footprint plots (Fig. 3) were quite similar with high particle residence time over the North Atlantic Ocean. None of the samples are taken during mineral dust events, which normally occur in spring at Jungfraujoch (Coen et al., 2007). One total aerosol sample with a higher fraction of carbonaceous particles had a higher surface residence time over the Po Valley than the rest.

\subsection{Ice nucleation activity of different particle groups}

IRs mainly consist of mineral particles (Fig. 6). The classes of Fe aluminosilicates, Ca sulfates, Ca-rich particles, silica, sea-salt-containing particles, and metal/metal oxides are enriched similar to aluminosilicates (odds ratio $\sim 1$ ). Other aluminosilicates are more enriched than aluminosilicates by a factor of $\sim 2$. The mineral particles' abundance between $60 \%$ and $85 \%$ in the IR fraction is in good agreement with previous findings for mixed-phase clouds at Jungfraujoch (Kamphus et al., 2010; Ebert et al., 2011; Worringen et al., 2015). Mineral particles are also reported as ice active in cirrus clouds (DeMott et al., 2003; Cziczo and Froyd, 2014). Studies of IRs in cirrus clouds are mentioned sometimes in the discussion to show which kinds of IRs are found in the environment, independent on the cloud regime. It has to be emphasized here that this is not meant as a direct comparison as the temperature and freezing regimes are quite different; note that deposition nucleation dominates in cirrus clouds (Cziczo et al., 2013).

The size of IRs varies between the detection limit $(100 \mathrm{~nm})$ and $3.4 \mu \mathrm{m}$ (Fig. 7). The size distribution is comparable to previous findings by Worringen et al. (2015) showing a maximum around $300 \mathrm{~nm}$. We did not find a relationship between the size of the particles and the enrichment factor (odds ratio), presumably because the particle size did not differ much.

The sampling temperature at the site varied between -10 and $-18^{\circ} \mathrm{C}$ (Fig. 2). Temperature was measured at the station and can differ from the onset ice nucleation temperature of the particles depending on where in the mixed-phase cloud nucleation occurred. None of the particle group abundances in the IR fraction showed a systematic temperature dependence. However, based on the limited number of samples and the relatively small temperature range, no definite conclusion regarding the temperature dependence can be drawn.

The importance of a given particle group for ice nucleation in the atmosphere depends on the ice nucleation ability and the abundance of this group in the total aerosol. Both parameters will be discussed in the following. Complex secondary aerosol particles and soot were not found in the IR fraction, in contrast to previous work at Jungfraujoch (Cozic et al., 2008a; Ebert et al., 2011; Worringen et al., 2015; Schmidt et al., 2017), even though these groups dominate the total aerosol fraction. Thus, their ice-nucleating ability under the conditions of our campaign can be assumed to be very low. One explanation for this difference might be the higher site temperatures during our campaign. In the present study, complex secondary particles are defined by the presence of an S peak in the X-ray spectrum and/or the instability under electron bombardment. It must be emphasized here that this particle group most likely also consists of a substantial fraction of organics and nitrates (Vester et al., 2007), see Table 1.

C-rich particles were observed in the total aerosol and the IR fraction but are less ice active than aluminosilicates (odds ratio 0.04). C-rich particles are reported in previous studies of mixed-phase clouds at Jungfraujoch (Mertes et al., 2007; Cozic et al., 2008; Kamphus et al., 2010; Ebert et al., 2011; Worringen et al., 2015; Schmidt et al., 2017). Our results are also in agreement with findings of many cirrus cloud field studies (see recent review by Knopf et al., 2018, and references therein), which show that organic aerosol is found in the IR fraction but is depleted relative to total aerosol.

Aluminosilicates are enriched in all samples and have the highest relative number abundance in the IR fraction. Aluminosilicates are also found to be efficient ice nuclei in other field experiments (Cziczo et al., 2013; Worringen et al., 2015; Iwata and Matsuki, 2018). Among aluminosilicates, kaolinite is reported as efficient ice nucleus in laboratory studies (Zimmermann et al., 2007; Murray et al., 2011; Wex et al., 2014; Freedman, 2015). As aluminosilicates often have a high abundance in the total aerosol and in the IR samples, they are the most important particle group for ice nucleation. Therefore the enrichment or depletion of the particle groups was normalized to this group.

Silica is the second most abundant mineral particle group in the IR samples and the only mineral group which seems to have a somewhat lower ice activity than aluminosilicates (upper limit of $95 \%$ confidence interval of the odds ratio $<1)$. However, keeping in mind the counting error for aluminosilicates, silica is statistically similarly enriched. This observation is in agreement with Atkinson et al. (2013) but in contradiction to Eastwood et al. (2008), who concluded that quartz is less ice active than kaolinite and montmorillonite. The silica fraction in the IR samples varies between $1 \%$ and $30 \%$. Boose et al. (2016) point out that quartz is always present in atmospheric dust in all size ranges, even in 
the smallest size fraction, which is dominated by clay minerals. They conclude that quartz is an important atmospheric INP component because it is present in the size fraction with the longest atmospheric residence time. Despite the fact that the enrichment of silica is somewhat lower than aluminosilicate, the relative high abundance in the IR fraction in our samples confirms this conclusion.

Fe aluminosilicates are similarly enriched in the IR fraction as aluminosilicates. Fe aluminosilicates were reported as cloud residual by Matsuki et al. (2010). As these authors did not differentiate between droplet and ice crystals, nothing can be said about the ice nucleation ability of Fe aluminosilicates. This mineral group is not present at high relative abundance at Jungfraujoch; thus, it will not contribute much to ice nucleation at this location.

The group of other aluminosilicates most likely consists of different minerals like feldspars, illite, and smectite. Laboratory studies (Atkinson et al., 2013; Iwata and Matsuki, 2018) showed that $\mathrm{K}$ feldspar and clay minerals (Zimmermann et al., 2008; Hiranuma et al., 2015; Boose et al., 2016) have a high ice nucleation ability compared to other minerals. A high ice nucleation ability of clay minerals is also reported from field experiments (Targino et al., 2006; Worringen et al., 2015). Also, our field study shows an enrichment of other aluminosilicates in the IR fraction, indicating a high ice nucleation ability. However, as feldspar is less common in the smallest dust fraction, it was concluded by Boose et al. (2016) that at least the feldspar group is generally of minor importance.

Ca-rich and Ca-sulfate particles are relatively low in number concentration, both in total aerosol and IR samples. Similar to quartz, calcium-containing particles showed different ice nucleation ability in previous laboratory studies (Zimmermann et al., 2008; Atkinson et al., 2013). In field experiments, however, Ca-rich particles and $\mathrm{Ca}$ sulfates were observed in the IR fraction (Ebert et al., 2011; Worringen et al., 2015; Iwata and Matsuki, 2018).

Based on chemistry, three subgroups of salt can be distinguished in the IR samples: pure salt, aged sea salt, and mixed sea salt. The pure salt is regarded as an artefact (see Sect. 2.6.1.) and thus excluded from the further analysis. Due to their low number abundance, the two other salt subgroups are combined into the sea-salt-containing particles group. Sea-salt-containing particles is enriched similar to aluminosilicates. The ice activity of salt and sea salt is still controversial due to discrepancies among different laboratory studies (Wise et al., 2012; Niehaus and Cantrell, 2015; Ladino et al., 2016). Kanji et al. (2017) assign these differences to the experimental set-up, i.e. different size, composition, and particle generation methods. In field experiments, however, salts are present in the IR fraction of both cirrus and mixedphase clouds (Targino et al., 2006; Ebert et al., 2011; Cziczo et al., 2013; Worringen et al., 2015; Iwata and Matsuki, 2018). It is advocated by Iwata and Matsuki (2018) that pure $\mathrm{NaCl}$ is not ice active due to molar depression of the freezing point. Sea-salt-containing particles may act as an INP due to the presence of organics (Wilson et al., 2015; DeMott et al., 2016; Iwata and Matsuki, 2018). However, we cannot define where the ice nucleation occurs in a particle, i.e. pores or thin coating, with our measurement technique.

The enrichment of metal and metal oxides is similar to aluminosilicates. The ice activity of different metal and metal oxide particles varies with their chemical composition (Kanji et al., 2017). Our samples are dominated by FeCrMn (steel), $\mathrm{Ti}$ oxide, and $\mathrm{Fe}$ oxide. Literature regarding the metal/metal oxide group is ambiguous. Hematite was reported as ice active by Zimmermann et al. (2008). In contrast, hematite, magnetite, and rutile were found not to be very ice active in deposition mode by Yakobi-Hancock et al. (2013). Even so, metal and metal oxides are often found in IR samples from cirrus and mixed-phase clouds (Kamphus et al., 2010; DeMott et al., 2003; Ebert et al., 2011; Worringen et al., 2015; Schmidt et al., 2017).

$\mathrm{Pb}$-containing particles are present in the IR fraction as already reported in previous work at Jungfraujoch (Cziczo et al., 2009; Kamphus et al., 2010; Ebert et al., 2011; Worringen et al., 2015; Schmidt et al., 2017). In the present study, $\mathrm{Pb}-$ rich particles are the most enriched particle group. A high enrichment of $\mathrm{Pb}$-rich particles among IRs was also reported by Ebert et al. (2011). In addition, laboratory work showed that $\mathrm{Pb}$ can increase the ice activity of mineral particles considerably (Cziczo et al., 2009; Yakobi-Hancock et al., 2013). Helicopters and small aircrafts were discussed as local sources of $\mathrm{Pb}$ at Jungfraujoch by Kamphus et al. (2010) and Ebert et al. (2011). As the samples were collected during in-cloud conditions, we do not expect $\mathrm{Pb}$-rich particles emitted freshly on-site from the mentioned sources. A time delay between emission and sampling results in relatively low concentrations of $\mathrm{Pb}$ in the ambient air in clouds at Jungfraujoch. However, Kamphus et al. (2010) and Schmidt et al. (2017) detected $\mathrm{Pb}$-bearing particles with mass spectrometry in both ambient air and IRs. Keeping in mind the better counting statistics of mass spectrometry, it seems plausible that total aerosol contains a small amount of $\mathrm{Pb}$-rich particles which were missed in our total samples.

To summarize, the two particle groups of complex secondary particles and soot are strongly depleted compared to aluminosilicates as well as absolutely depleted compared to the total aerosol. Despite an uncertainty due to potential misclassification, the $\mathrm{C}$-rich group is less enriched compared to aluminosilicates. Other aluminosilicates and $\mathrm{Pb}$-rich particles are enriched compared to aluminosilicates. A high enrichment of $\mathrm{Pb}$-rich particles indicates that this group is more ice active than the rest of the groups present in the IR fraction. All other particle groups (silica, Fe aluminosilicates, $\mathrm{Ca}$ sulfates, Ca-rich particles, sea-salt-containing particles, and metal/metal oxides) are enriched similar to aluminosilicate. The relatively high abundance of artefacts was identified by comparing the IR and total aerosol fraction, showing how important parallel sampling is for identification of IRs. Tak- 
ing into account the relative abundance of the particle groups in total aerosol and the ice nucleation ability, we conclude that silica, aluminosilicates, and other aluminosilicates were the most important ice-nucleating particles in mixed-phase clouds at site temperatures between -10 and $-18^{\circ} \mathrm{C}$ during the campaign at Jungfraujoch in winter 2017.

Data availability. The data set is available for the community and can be accessed by request to Stine Eriksen Hammer (sehammer@geo.tu-darmstadt.de) of the Technical University Darmstadt.

Supplement. The supplement related to this article is available online at: https://doi.org/10.5194/acp-18-13987-2018-supplement.

Author contributions. SEH collected the samples, analysed the particles by electron microscopy, performed data analysis, and prepared the paper. ME contributed to electron microscopy and data analysis. KK designed the dilution unit and contributed to data analysis. SM designed, improved, and operated the Ice-CVI during the campaign. JS organized the field campaign at Jungfraujoch and contributed to data analysis. SW contributed to data analysis and paper preparation.

Competing interests. The authors declare that they have no conflict of interest.

Special issue statement. This article is part of the special issue "Results from the ice nucleation research unit (INUIT) (ACP/AMT inter-journal SI)". It is not associated with a conference.

Acknowledgements. Stine Eriksen Hammer would like to thank Annette Worringen and Nathalie Benker for discussion and support and Thomas Dirsch for building the dilution unit. We thank the whole INUIT-JFJ team for discussions and support. The authors thank MeteoSwiss for meteorological data and the International Foundation HFSJG, who made it possible to carry out the experiment at the high-altitude research station Jungfraujoch. The authors also gratefully acknowledge the German Research Foundation for financial support within the research group INUIT - INUIT (FOR 1525 ) and within grant KA 2280/2-1.

This project has received funding from the European Union's Horizon 2020 research and innovation programme under grant agreement no. 654109 .

Edited by: Allan Bertram

Reviewed by: two anonymous referees

\section{References}

Aitchison, J.: A concise guide to compositional data analysis, Cairndow, UK, 2003.

Atkinson, J. D., Murray, B. J., Woodhouse, M. T., Whale, T. F., Baustian, K. J., Carslaw, K. S., Dobbie, S., O’Sullivan, D., and Malkin, T. L.: The importance of feldspar for ice nucleation by mineral dust in mixed-phase clouds, Nature, 498, 355-358, https://doi.org/10.1038/nature12278, 2013.

Boose, Y., Welti, A., Atkinson, J., Ramelli, F., Danielczok, A., Bingemer, H. G., Plötze, M., Sierau, B., Kanji, Z. A., and Lohmann, U.: Heterogeneous ice nucleation on dust particles sourced from nine deserts worldwide - Part 1: Immersion freezing, Atmos. Chem. Phys., 16, 15075-15095, https://doi.org/10.5194/acp-16-15075-2016, 2016.

Buseck, P. R., Adachi, K., Gelencsér, A., Tompa, É., and Pósfai, M.: Ns-Soot: A Material-Based Term for Strongly LightAbsorbing Carbonaceous Particles, Aerosol Sci. Tech., 48, 777788, https://doi.org/10.1080/02786826.2014.919374, 2014.

Carlslaw, D. C. and Ropkins, K.: Openair - an R package for air quality data analysis, Environ. Modell. Softw., 27-28, 52-61, https://doi.org/10.1016/j.envsoft.2011.09.008, 2012.

Choël, M., Deboudt, K., Osán, J., Flament, P., and Van Grieken, R.: Quantitative Determination of Low-Z Elements in Single Atmospheric Particles on Boron Substrates by Automated Scanning Electron Microscopy-EnergyDispersive X-ray Spectrometry, Anal. Chem., 77, 5686-5692, https://doi.org/10.1021/ac050739x, 2005.

Coen, M. C., Weingartner, E., Nyeki, S., Cozic, J., Henning, S., Verheggen, B., Gehrig, R., and Baltensperger, U.: Longterm trend analysis of aerosol variables at the high-alpine site Jungfraujoch, J. Geophys. Res.-Atmos., 112, D13213, https://doi.org/10.1029/2006JD007995, 2007.

Cozic, J., Mertes, S., Verheggen, B., Cziczo, D. J., Gallavardin, S. J., Walter, S., Baltensperger, U., and Weingartner, E.: Black carbon enrichment in atmospheric ice particle residuals observed in lower tropospheric mixed phase clouds, J. Geophys. Res.Atmos., 113, D15209, https://doi.org/10.1029/2007JD009266, 2008a.

Cozic, J., Verheggen, B., Weingartner, E., Crosier, J., Bower, K. N., Flynn, M., Coe, H., Henning, S., Steinbacher, M., Henne, S., Collaud Coen, M., Petzold, A., and Baltensperger, U.: Chemical composition of free tropospheric aerosol for PM1 and coarse mode at the high alpine site Jungfraujoch, Atmos. Chem. Phys., 8, 407-423, https://doi.org/10.5194/acp-8-407-2008, 2008 b.

Cziczo, D. J. and Froyd, K. D.: Sampling the composition of cirrus ice residuals, Atmos. Res., 142, 15-31, https://doi.org/10.1016/j.atmosres.2013.06.012, 2014.

Cziczo, D. J., DeMott, P. J., Brooks, S. D., Prenni, A. J., Thomson, D. S., Baumgardner, D., Wilson, J. C., Kreidenweis, S. M., and Murphy, D. M.: Observations of organic species and atmospheric ice formation, Geophys. Res. Lett., 31, L12116, https://doi.org/10.1029/2004GL019822, 2004.

Cziczo, D. J., Stetzer, O., Worringen, A., Ebert, M., Weinbruch, S., Kamphus, M., Gallavardin, S. J., Curtius, J., Borrmann, S., and Froyd, K. D.: Inadvertent climate modification due to anthropogenic lead, Nat. Geosci., 2, 333-336, https://doi.org/10.1038/ngeo499, 2009.

Cziczo, D. J., Froyd, K. D., Hoose, C., Jensen, E. J., Diao, M., Zondlo, M. A., Smith, J. B., Twohy, C. H., and Mur- 
phy, D. M.: Clarifying the Dominant Sources and Mechanisms of Cirrus Cloud Formation, Science, 340, 1320-1324, https://doi.org/10.1126/science.1234145, 2013.

Cziczo, D. J., Ladino, L., Boose, Y., Kanji, Z. A., Kupiszewski, P., Lance, S., Mertes, S., and Wex, H.: Measurements of Ice Nucleating Particles and Ice Residuals, Meteor. Mon., 58, 8.1-8.13, https://doi.org/10.1175/amsmonographs-d-16-0008.1, 2017.

DeMott, P., Cziczo, D., Prenni, A., Murphy, D., Kreidenweis, S., Thomson, D., Borys, R., and Rogers, D.: Measurements of the concentration and composition of nuclei for cirrus formation, P. Natl. Acad. Sci. USA, 100, 14655-14660, https://doi.org/10.1073/pnas.2532677100, 2003.

DeMott, P. J., Hill, T. C. J., McCluskey, C. S., Prather, K. A., Collins, D. B., Sullivan, R. C., Ruppel, M. J., Mason, R. H., Irish, V. E., Lee, T., Hwang, C. Y., Rhee, T. S., Snider, J. R., McMeeking, G. R., Dhaniyala, S., Lewis, E. R., Wentzell, J. J. B., Abbatt, J., Lee, C., Sultana, C. M., Ault, A. P., Axson, J. L., Diaz Martinez, M., Venero, I., Santos-Figueroa, G., Stokes, M. D., Deane, G. B., Mayol-Bracero, O. L., Grassian, V. H., Bertram, T. H., Bertram, A. K., Moffett, B. F., and Franc, G. D.: Sea spray aerosol as a unique source of ice nucleating particles, P. Natl. Acad. Sci. USA, 113, 5797-5803, https://doi.org/10.1073/pnas.1514034112, 2016.

Eastwood, M. L., Cremel, S., Gehrke, C., Girard, E., and Bertram, A. K.: Ice nucleation on mineral dust particles: Onset conditions, nucleation rates and contact angles, J. Geophys. Res.-Atmos., 113, D22203, https://doi.org/10.1029/2008JD010639, 2008.

Ebert, M., Worringen, A., Benker, N., Mertes, S., Weingartner, E., and Weinbruch, S.: Chemical composition and mixing-state of ice residuals sampled within mixed phase clouds, Atmos. Chem. Phys., 11, 2805-2816, https://doi.org/10.5194/acp-112805-2011, 2011.

Ebert, M., Weigel, R., Kandler, K., Günther, G., Molleker, S., Grooß, J.-U., Vogel, B., Weinbruch, S., and Borrmann, S.: Chemical analysis of refractory stratospheric aerosol particles collected within the arctic vortex and inside polar stratospheric clouds, Atmos. Chem. Phys., 16, 8405-8421, https://doi.org/10.5194/acp-16-8405-2016, 2016.

Flato, G., Marotzke, J., Abiodun, B., Braconnot, P., Chou, S. C., Collins, W. J., Cox, P., Driouech, F., Emori, S., Eyring, V., Forest, C., Gleckler, P., Guilyardi, E., Jakob, C., Kattsov, V., Reason, C., and Rummukaines, M.: Evaluation of Climate Models, in: Climate Change 2013: The Physical Science Basis. Contribution of Working Group I to the Fifth Assessment Report of the Intergovernmental Panel on Climate Change, Assessment Reports of IPCC, edited by: Stocker, T. F., Qin, D., Plattner, G.-K., Tignor, M., Allen, S. K., Boschung, J., Nauels, A., Xia, Y., Bex, V., and Midgley, P. M., Cambridge University Press, Cambridge, UK and New York, NY, USA, 741-866, available at: https://www.ipcc.ch/pdf/assessment-report/ar5/wg1/WG1AR5_ Chapter09_FINAL.pdf (last access: 13 March 2017), 2013.

Freedman, M. A.: Potential Sites for Ice Nucleation on Aluminosilicate Clay Minerals and Related Materials, J. Phys. Chem. Lett., 6, 3850-3858, https://doi.org/10.1021/acs.jpclett.5b01326, 2015.

Fröhlich, R., Cubison, M. J., Slowik, J. G., Bukowiecki, N., Canonaco, F., Croteau, P. L., Gysel, M., Henne, S., Herrmann, E., Jayne, J. T., Steinbacher, M., Worsnop, D. R., Baltensperger, U., and Prévôt, A. S. H.: Fourteen months of on-line measure- ments of the non-refractory submicron aerosol at the Jungfraujoch (3580 ma.s.1.) - chemical composition, origins and organic aerosol sources, Atmos. Chem. Phys., 15, 11373-11398, https://doi.org/10.5194/acp-15-11373-2015, 2015.

Froyd, K. D., Murphy, D. M., Lawson, P., Baumgardner, D., and Herman, R. L.: Aerosols that form subvisible cirrus at the tropical tropopause, Atmos. Chem. Phys., 10, 209-218, https://doi.org/10.5194/acp-10-209-2010, 2010.

Hallett, J. and Mossop, S. C.: Production of secondary ice particles during the riming process, Nature, 249, 26-28, https://doi.org/10.1038/249026a0, 1974.

Heintzenberg, J., Okada, K., and Ström, J.: On the composition of non-volatile material in upper tropospheric aerosols and cirrus crystals, Atmos. Res., 41, 81-88, https://doi.org/10.1016/01698095(95)00042-9, 1996.

Herrmann, E., Weingartner, E., Henne, S., Vuilleumier, L., Bukowiecki, N., Steinbacher, M., Conen, F., Collaud Coen, M., Hammer, E., and Jurányi, Z.: Analysis of long-term aerosol size distribution data from Jungfraujoch with emphasis on free tropospheric conditions, cloud influence, and air mass transport, J. Geophys. Res.-Atmos., 120, 9459-9480, https://doi.org/10.1002/2015JD023660, 2015.

Hiranuma, N., Augustin-Bauditz, S., Bingemer, H., Budke, C., Curtius, J., Danielczok, A., Diehl, K., Dreischmeier, K., Ebert, M., Frank, F., Hoffmann, N., Kandler, K., Kiselev, A., Koop, T., Leisner, T., Möhler, O., Nillius, B., Peckhaus, A., Rose, D., Weinbruch, S., Wex, H., Boose, Y., DeMott, P. J., Hader, J. D., Hill, T. C. J., Kanji, Z. A., Kulkarni, G., Levin, E. J. T., McCluskey, C. S., Murakami, M., Murray, B. J., Niedermeier, D., Petters, M. D., O’Sullivan, D., Saito, A., Schill, G. P., Tajiri, T., Tolbert, M. A., Welti, A., Whale, T. F., Wright, T. P., and Yamashita, K.: A comprehensive laboratory study on the immersion freezing behavior of illite NX particles: a comparison of 17 ice nucleation measurement techniques, Atmos. Chem. Phys., 15, 2489-2518, https://doi.org/10.5194/acp-15-2489-2015, 2015.

Hoose, C., Lohmann, U., Erdin, R., and Tegen, I.: The global influence of dust mineralogical composition on heterogeneous ice nucleation in mixed-phase clouds, Environ. Res. Lett., 3, 025003, https://doi.org/10.1088/1748-9326/3/2/025003, 2008.

Hoose, C., Kristjánsson, J. E., and Burrows, S. M.: How important is biological ice nucleation in clouds on a global scale?, Environ. Res. Lett., 5, 024009, https://doi.org/10.1088/17489326/5/2/024009, 2010.

Hoose, C. and Möhler, O.: Heterogeneous ice nucleation on atmospheric aerosols: a review of results from laboratory experiments, Atmos. Chem. Phys., 12, 9817-9854, https://doi.org/10.5194/acp-12-9817-2012, 2012.

Iwata, A. and Matsuki, A.: Characterization of individual ice residual particles by the single droplet freezing method: a case study in the Asian dust outflow region, Atmos. Chem. Phys., 18, 17851804, https://doi.org/10.5194/acp-18-1785-2018, 2018.

Kamphus, M., Ettner-Mahl, M., Klimach, T., Drewnick, F., Keller, L., Cziczo, D. J., Mertes, S., Borrmann, S., and Curtius, J.: Chemical composition of ambient aerosol, ice residues and cloud droplet residues in mixed-phase clouds: single particle analysis during the Cloud and Aerosol Characterization Experiment (CLACE 6), Atmos. Chem. Phys., 10, 8077-8095, https://doi.org/10.5194/acp-10-8077-2010, 2010. 
Kanji, Z. A., Ladino, L. A., Wex, H., Boose, Y., BurkertKohn, M., Cziczo, D. J., and Krämer, M.: Overview of Ice Nucleating Particles, Meteor. Mon., 58, 1.1-1.33, https://doi.org/10.1175/AMSMONOGRAPHS-D-16-0006.1, 2017.

Knopf, D. A., Alpert, P. A., and Wang, B.: The Role of Organic Aerosol in Atmospheric Ice Nucleation: A Review, ACS Earth Space Chem., 2, 168-202, https://doi.org/10.1021/acsearthspacechem.7b00120, 2018.

Korolev, A., McFarquhar, G., Field, P. R., Franklin, C., Lawson, P., Wang, Z., Williams, E., Abel, S. J., Axisa, D., Borrmann, S., Crosier, J., Fugal, J., Krämer, M., Lohmann, U., Schlenczek, O., Schnaiter, M., and Wendisch, M.: Mixed-Phase Clouds: Progress and Challenges, Meteor. Mon., 58, 5.1-5.50, https://doi.org/10.1175/amsmonographs-d-17-0001.1, 2017.

Ladino, L. A., Yakobi-Hancock, J. D., Kilthau, W. P., Mason, R. H., Si, M., Li, J., Miller, L. A., Schiller, C. L., Huffman, J. A., Aller, J. Y., Knopf, D. A., Bertram, A. K., and Abbatt, J. P. D.: Addressing the ice nucleating abilities of marine aerosol: A combination of deposition mode laboratory and field measurements, Atmos. Environ., 132, 1-10, https://doi.org/10.1016/j.atmosenv.2016.02.028, 2016.

Lohmann, U. and Diehl, K.: Sensitivity Studies of the Importance of Dust Ice Nuclei for the Indirect Aerosol Effect on Stratiform Mixed-Phase Clouds, J. Atmos. Sci., 63, 968-982, https://doi.org/10.1175/jas3662.1, 2006.

Matsuki, A., Schwarzenboeck, A., Venzac, H., Laj, P., Crumeyrolle, S., and Gomes, L.: Cloud processing of mineral dust: direct comparison of cloud residual and clear sky particles during AMMA aircraft campaign in summer 2006, Atmos. Chem. Phys., 10, 1057-1069, https://doi.org/10.5194/acp-10-1057-2010, 2010.

Mertes, S., Verheggen, B., Walter, S., Connolly, P., Ebert, M., Schneider, J., Bower, K. N., Cozic, J., Weinbruch, S., Baltensperger, U., and Weingartner, E.: Counterflow Virtual Impactor Based Collection of Small Ice Particles in Mixed-Phase Clouds for the Physico-Chemical Characterization of Tropospheric Ice Nuclei: Sampler Description and First Case Study, Aerosol Sci. Tech., 41, 848-864, https://doi.org/10.1080/02786820701501881, 2007.

Murray, B. J., Broadley, S. L., Wilson, T. W., Atkinson, J. D., and Wills, R. H.: Heterogeneous freezing of water droplets containing kaolinite particles, Atmos. Chem. Phys., 11, 4191-4207, https://doi.org/10.5194/acp-11-4191-2011, 2011.

Myhre, G., Shindell, D., Bréon, F.-M., Collins, W., Fuglestvedt, J., Huang, J., Koch, D., Lamarque, J.-F., Lee, D., Mendoza, B., Nakajima, T., Robock, A., Stephens, G., Takemura, T., and Zhang, H.: Anthropogenic and Natural Radiative Forcing, in: Climate Change 2013: The Physical Science Basis, Contribution of Working Group I to the Fifth Assessment Report of the Intergovernmental Panel on Climate Change, edited by: Stocker, T. F., Qin, D., Plattner, G.-K., Tignor, M., Allen, S. K., Boschung, J., Nauels, A., Xia, Y., Bex, V., and Midgley, P. M., Cambridge University Press, Cambridge, UK and New York, NY, USA, 2013.

Niehaus, J. and Cantrell, W.: Contact Freezing of Water by Salts, J. Phys. Chem. Lett., 6, 3490-3495, https://doi.org/10.1021/acs.jpclett.5b01531, 2015.

Ogren, J. A., Heintzenberg, J., and Charlson, R. J.: In-situ sampling of clouds with a droplet to aerosol converter, Geophys. Res. Lett., 12, 121-124, https://doi.org/10.1029/GL012i003p00121, 1985.
Ogren, J. A., Heintzenberg, J., and Charlson, R. J.: In-Situ Sampling of Clouds with a Droplet to Aerosol Converter, Geophys. Res. Lett., 12, 121-124, https://doi.org/10.1029/GL012i003p00121, 1985.

RStudio Team: RStudio: Integrated Development for R, RStudio Inc., Boston, MA, available at: http://www.rstudio.com/ (last access: 9 March 2018), 2016.

Schmidt, S., Schneider, J., Klimach, T., Mertes, S., Schenk, L. P., Kupiszewski, P., Curtius, J., and Borrmann, S.: Online single particle analysis of ice particle residuals from mountain-top mixedphase clouds using laboratory derived particle type assignment, Atmos. Chem. Phys., 17, 575-594, https://doi.org/10.5194/acp17-575-2017, 2017.

Schütze, K., Wilson, J. C., Weinbruch, S., Benker, N., Ebert, M., Günther, G., Weigel, R., and Borrmann, S.: Sub-micrometer refractory carbonaceous particles in the polar stratosphere, Atmos. Chem. Phys., 17, 12475-12493, https://doi.org/10.5194/acp-1712475-2017, 2017.

Seibert, P. and Frank, A.: Source-receptor matrix calculation with a Lagrangian particle dispersion model in backward mode, Atmos. Chem. Phys., 4, 51-63, https://doi.org/10.5194/acp-4-512004, 2004.

Stohl, A., Hittenberger, M., and Wotawa, G.: Validation of the lagrangian particle dispersion model FLEXPART against largescale tracer experiment data, Atmos. Environ., 32, 4245-4264, https://doi.org/10.1016/S1352-2310(98)00184-8, 1998.

Stohl, A. and Thomson, D. J.: A Density Correction for Lagrangian Particle Dispersion Models, Bound.-Lay. Meteorol., 90, 155167, https://doi.org/10.1023/a:1001741110696, 1999.

Stohl, A., Forster, C., Frank, A., Seibert, P., and Wotawa, G.: Technical note: The Lagrangian particle dispersion model FLEXPART version 6.2, Atmos. Chem. Phys., 5, 2461-2474, https://doi.org/10.5194/acp-5-2461-2005, 2005.

Storelvmo, T.: Aerosol Effects on Climate via Mixed-Phase and Ice Clouds, Annu. Rev. Earth Planet. Sci., 45, 199-222, https://doi.org/10.1146/annurev-earth-060115-012240, 2017.

Ström, J. and Ohlsson, S.: Real-time measurement of absorbing material in contrail ice using a counterflow virtual impactor, J. Geophys. Res.-Atmos., 103, 8737-8741, https://doi.org/10.1029/98JD00425, 1998.

Targino, A. C., Krejci, R., Noone, K. J., and Glantz, P.: Single particle analysis of ice crystal residuals observed in orographic wave clouds over Scandinavia during INTACC experiment, Atmos. Chem. Phys., 6, 1977-1990, https://doi.org/10.5194/acp-61977-2006, 2006.

Twohy, C. H., Strapp, J. W., and Wendisch, M.: Performance of a Counterflow Virtual Impactor in the NASA Icing Research Tunnel, J. Atmos. Ocean. Tech., 20, 781-790, https://doi.org/10.1175/15200426(2003)020<0781:poacvi>2.0.co;2, 2003.

Twohy, C. H. and Poellot, M. R.: Chemical characteristics of ice residual nuclei in anvil cirrus clouds: evidence for homogeneous and heterogeneous ice formation, Atmos. Chem. Phys., 5, 22892297, https://doi.org/10.5194/acp-5-2289-2005, 2005.

Vali, G., DeMott, P. J., Möhler, O., and Whale, T. F.: Technical Note: A proposal for ice nucleation terminology, Atmos. Chem. Phys., 15, 10263-10270, https://doi.org/10.5194/acp-15-102632015, 2015. 
Van den Boogaart, K. G. and Tolosana-Delgado, R.: Analyzing compositional data with R, Springer, Berlin, 2013.

Vester, B. P., Ebert, M., Barnert, E. B., Schneider, J., Kandler, K., Schütz, L., and Weinbruch, S.: Composition and mixing state of the urban background aerosol in the RheinMain area (Germany), Atmos. Environ., 41, 6102-6115, https://doi.org/10.1016/j.atmosenv.2007.04.021, 2007.

Weinbruch, S., Benker, N., Kandler, K., Schütze, K., Kling, K., Berlinger, B., Thomassen, Y., Drotikova, T., and Kallenborn, R.: Source identification of individual soot agglomerates in Arctic air by transmission electron microscopy, Atmos. Environ., 172, 47-54, https://doi.org/10.1016/j.atmosenv.2017.10.033, 2018.

Weingartner, E., Nyeki, S., and Baltensperger, U.: Seasonal and diurnal variation of aerosol size distributions $(10<\mathrm{D}<750 \mathrm{~nm})$ at a high-alpine site (Jungfraujoch 3580 m a.s.1.), J. Geophys. Res.-Atmos., 104, 26809-26820, https://doi.org/10.1029/1999JD900170, 1999.

Wentzel, M., Gorzawski, H., Naumann, K. H., Saathoff, H., and Weinbruch, S.: Transmission electron microscopical and aerosol dynamical characterization of soot aerosols, J. Atmos. Sci., 34, 1347-1370, https://doi.org/10.1016/S0021-8502(03)003604, 2003.

Wex, H., DeMott, P. J., Tobo, Y., Hartmann, S., Rösch, M., Clauss, T., Tomsche, L., Niedermeier, D., and Stratmann, F.: Kaolinite particles as ice nuclei: learning from the use of different kaolinite samples and different coatings, Atmos. Chem. Phys., 14, 55295546, https://doi.org/10.5194/acp-14-5529-2014, 2014.

Wickham, H.: ggplot2: Elegant Graphics for Data Analysis, Springer-Verlag New York, New York, 2009.

Wilson, T. W., Ladino, L. A., Alpert, P. A., Breckels, M. N., Brooks, I. M., Burrows, S. M., Carslaw, K. S., Huffman, J. A., Judd, C., and Kilthau, W. P.: A marine biogenic source of atmospheric ice-nucleating particles, Nature, 525, 234-238, https://doi.org/10.1038/nature14986, 2015.
Wise, M. E., Baustian, K. J., Koop, T., Freedman, M. A., Jensen, E. J., and Tolbert, M. A.: Depositional ice nucleation onto crystalline hydrated $\mathrm{NaCl}$ particles: a new mechanism for ice formation in the troposphere, Atmos. Chem. Phys., 12, 1121-1134, https://doi.org/10.5194/acp-12-1121-2012, 2012.

Worringen, A., Kandler, K., Benker, N., Dirsch, T., Mertes, S., Schenk, L., Kästner, U., Frank, F., Nillius, B., Bundke, U., Rose, D., Curtius, J., Kupiszewski, P., Weingartner, E., Vochezer, P., Schneider, J., Schmidt, S., Weinbruch, S., and Ebert, M.: Single-particle characterization of ice-nucleating particles and ice particle residuals sampled by three different techniques, Atmos. Chem. Phys., 15, 4161-4178, https://doi.org/10.5194/acp15-4161-2015, 2015.

Yakobi-Hancock, J. D., Ladino, L. A., and Abbatt, J. P. D.: Feldspar minerals as efficient deposition ice nuclei, Atmos. Chem. Phys., 13, 11175-11185, https://doi.org/10.5194/acp-13-11175-2013, 2013.

Zimmermann, F., Ebert, M., Worringen, A., Schütz, L., and Weinbruch, S.: Environmental scanning electron microscopy (ESEM) as a new technique to determine the ice nucleation capability of individual atmospheric aerosol particles, Atmos. Environ., 41, 8219-8227, https://doi.org/10.1016/j.atmosenv.2007.06.023, 2007.

Zimmermann, F., Weinbruch, S., Schütz, L., Hofmann, H., Ebert, M., Kandler, K., and Worringen, A.: Ice nucleation properties of the most abundant mineral dust phases, J. Geophys. Res.-Atmos., 113, D23204, https://doi.org/10.1029/2008JD010655, 2008. 